\title{
Homologies of the head of Membracoidea based on nymphal morphology with notes on other groups of Auchenorrhyncha (Hemiptera)
}

\author{
DMITRY A. DMITRIEV \\ Illinois Natural History Survey, Institute of Natural Resource Sustainability at the University of Illinois at Urbana-Champaign, \\ Champaign, Illinois, USA; e-mail: dmitriev@inhs.uiuc.edu
}

Key words. Hemiptera, Membracoidea, Cicadellidae, Cicadoidea, Cercopoidea, Fulgoroidea, head, morphology, ground plan

\begin{abstract}
The ground plan and comparative morphology of the nymphal head of Membracoidea are presented with particular emphasis on the position of the clypeus, frons, epistomal suture, and ecdysial line. Differences in interpretation of the head structures in Auchenorrhyncha are discussed. Membracoidea head may vary more extensively than heads in any other group of insects. It is often modified by the development of an anterior carina, which apparently was gained and lost multiple times within Membracoidea. The main modifications of the head of Membracoidea and comparison of those changes with the head of other superfamilies of Auchenorrhyncha are described.
\end{abstract}

\section{INTRODUCTION}

The general morphology of the insect head is relatively well studied (Ferris, 1942, 1943, 1944; Cook, 1944; DuPorte, 1946; Snodgrass, 1947; Matsuda, 1965; Kukalová-Peck, 1985, 1987, 1991, 1992, 2008). There are also a few papers in which the hemipteran head is compared to the head of other insects (Ferris, 1943; Lew, 1960; DuPorte, 1962; Parsons, 1964; Evans, 1973; Hamilton, 1981). As mentioned by Evans (1975), the head of Membracoidea and leafhoppers (Cicadellidae) in particular may vary more extensively than in any other group of insects. Although the head of the closely related superfamily Fulgoroidea also exhibits considerable diversity in form, the differences are more of a superficial nature compared to the modifications of the head of Membracoidea. Only a few papers have been published on comparative morphology of the head of leafhoppers from different subfamilies (Spooner, 1938; Evans, 1938, 1957, 1968, 1975; Wagner, 1951; Dmitriev, 2001, 2002a, b, 2003, 2004a, b, 2006; Dietrich \& Dmitriev, 2003).

The head of Hemiptera is considerably modified compared to the mandibulate head of other insects due to a piercing and sucking mode of feeding. The papers mentioned above use slightly different interpretations of the homologies and terminology in comparisons of the hemipteran head to that of mandibulate insects (Table 1). This paper is not intended to evaluate different theories described in the morphological papers, but rather to describe the homologies among different groups of Membracoidea and compare the head of Membracoidea with other groups of Auchenorrhyncha (Cercopoidea, Cicadoidea, and Fulgoroidea). This paper uses the head terminology preferred in hemipteran morphological papers and comparable to the terminology used in other groups of insects (DuPorte, 1946, 1962; Lew, 1960; Snodgrass, 1935, 1947; Matsuda, 1965).

\section{MATERIAL AND METHODS}

Dried and pinned specimens were studied under an Olympus SZX12 microscope with SZX-DA drawing tube attachment. Detailed study of internal structures and boundaries of sclerites is based on examination of exuviae and specimens cleared in $5 \% \mathrm{KOH}$. All descriptions are based on the last instar nymphs of Auchenorrhyncha because they have more pronounced sutures dividing the head sclerites.

Material from the following collections was studied: Zoological Institute of the Russian Academy of Sciences (Russia, St. Petersburg); Illinois Natural History Survey (USA, Illinois, Champaign); Natural History Museum (Great Britain, London); National Museums \& Galleries of Wales (Great Britain, Cardiff); Muséum national d'Histoire naturelle (France, Paris); Museum für Naturkunde (Germany, Berlin); Ohio State University (USA, Ohio, Columbus); Zoological Museum (Russia, Moscow).

Classification mostly follows Oman et al. (1990) with some changes proposed by Dietrich \& Dmitriev (2003); Dietrich (2004); Dmitriev (2002b, 2004a, 2006); Zahniser \& Dietrich (2010).

\section{List of studied material}

(Groups are ordered according to the successive modifications of their heads).

Cicadoidea

Cicadidae. Exuviae of Tibicen sp. and some other species.

Cercopoidea

Cercopidae. Unidentified species.

Aphrophoridae. Philaenus spumarius (Linnaeus, 1758).

Fulgoroidea

Ricaniidae. Ricania japonica Melichar, 1898.

Delphacidae. Criomorphus borealis (Sahlberg, 1871), Muirodelphax parvula (Van Duzee, 1902).

Dictyopharidae. Scolops sulcipes (Say, 1825).

Acanaloniidae. Acanalonia conica (Say, 1830).

Fulgoridae. Unidentified species.

Membracoidea

Membracidae. Gargara genistae (Fabricius, 1775), Stictocephala bisonia Kopp \& Yonke, 1977, and numerous unidentified species from the New World. 
TABLE 1. Alternative interpretation of the head morphology and terminology used in systematic and morphological literature.

\begin{tabular}{|c|c|c|c|c|c|c|c|c|c|c|}
\hline This paper & Vertex & $\begin{array}{c}\text { Coronal } \\
\text { suture }\end{array}$ & Ecdysial line & Frons & $\begin{array}{l}\text { Post- } \\
\text { frons }\end{array}$ & $\begin{array}{l}\text { Epistomal } \\
\text { suture }\end{array}$ & Postclypeus & $\begin{array}{l}\text { Ante- } \\
\text { clypeus }\end{array}$ & Lorum & Maxillary plate \\
\hline $\begin{array}{l}\text { Snodgrass, } \\
1935,1947\end{array}$ & Vertex & $\begin{array}{l}\text { Coronal } \\
\text { stem of } \\
\text { ecdysial } \\
\text { cleavage } \\
\text { line } \\
\end{array}$ & $\begin{array}{c}\text { Arms of } \\
\text { ecdysial } \\
\text { cleavage line } \\
\text { (position } \\
\text { variable) }\end{array}$ & \multicolumn{2}{|c|}{$\begin{array}{l}\text { Frons (division, } \\
\text { if present, secon- } \\
\text { dary) }\end{array}$} & $\begin{array}{c}\text { Epistomal or } \\
\text { fronto- } \\
\text { clypeal } \\
\text { sulcus }\end{array}$ & Postclypeus & $\begin{array}{l}\text { Ante- } \\
\text { clypeus }\end{array}$ & $\begin{array}{c}\text { Lorum or } \\
\text { mandibular } \\
\text { plate (man- } \\
\text { dibular in ori- } \\
\text { gin) } \\
\end{array}$ & Maxillary plate \\
\hline Spooner, 1938 & Vertex & $\begin{array}{l}\text { Epicranial } \\
\text { stem }\end{array}$ & $\begin{array}{l}\text { Epicranial } \\
\text { arms }\end{array}$ & \multicolumn{2}{|c|}{ Frons } & $\begin{array}{l}\text { Fronto- } \\
\text { clypeal } \\
\text { suture }\end{array}$ & Postclypeus & $\begin{array}{l}\text { Ante- } \\
\text { clypeus }\end{array}$ & Paraclypeus & Maxillary plate \\
\hline $\begin{array}{l}\text { Ferris, 1942, } \\
\text { 1943; } \\
\text { Cook, } 1944\end{array}$ & $\begin{array}{l}\text { Vertex, } \\
\text { ocular } \\
\text { lobes }\end{array}$ & $\begin{array}{c}\text { Coronal } \\
\text { suture }\end{array}$ & $\begin{array}{l}\text { Postfrontal } \\
\text { suture }\end{array}$ & \multicolumn{2}{|c|}{ Frons } & $\begin{array}{c}\text { Clypeofron- } \\
\text { tal suture }\end{array}$ & \multicolumn{2}{|c|}{ Clypeus } & $\begin{array}{l}\text { Paraclypeal } \\
\text { lobe }\end{array}$ & \\
\hline $\begin{array}{l}\text { DuPorte, } \\
1946,1962\end{array}$ & Vertex & $\begin{array}{l}\text { Coronal } \\
\text { suture }\end{array}$ & \begin{tabular}{|c|} 
Frontal \\
suture (posi- \\
tion \\
variable)
\end{tabular} & \multicolumn{2}{|c|}{ Postfrons } & $\begin{array}{c}\text { Transfrontal } \\
\text { sulcus }\end{array}$ & $\begin{array}{c}\text { Fronto- } \\
\text { clypeus } \\
\text { (fused } \\
\text { antefrons and } \\
\text { postclypeus) }\end{array}$ & $\begin{array}{l}\text { Ante- } \\
\text { clypeus }\end{array}$ & Hypopharynx & \\
\hline Oman, 1949 & & & & & & & Clypeus & Clypellus & Lorum & Maxillary plate \\
\hline \begin{tabular}{|l|} 
Kramer, 1950; \\
Wagner, \\
$1951 ;$ \\
Lew, 1960 \\
\end{tabular} & Vertex & $\begin{array}{c}\text { Coronal } \\
\text { suture }\end{array}$ & $\begin{array}{l}\text { Postfrontal } \\
\text { suture }\end{array}$ & \multicolumn{2}{|c|}{ Frons } & $\begin{array}{l}\text { Epistomal } \\
\text { suture }\end{array}$ & Postclypeus & $\begin{array}{l}\text { Ante- } \\
\text { clypeus }\end{array}$ & Lorum & Maxillary plate \\
\hline $\begin{array}{l}\text { Parsons, 1964; } \\
\text { Bourgoin, } \\
1986 a\end{array}$ & & & & & & Postclypeus & $\begin{array}{l}\text { Ante- } \\
\text { clypeus }\end{array}$ & $\begin{array}{c}\text { Hypopharynx } \\
\text { (not appen- } \\
\text { dicular } \\
\text { structure) }\end{array}$ & $\begin{array}{l}\text { "Maxillary } \\
\text { plate" (genal- } \\
\text { postgenal not } \\
\text { appendicular } \\
\text { structure) }\end{array}$ \\
\hline $\begin{array}{l}\text { Matsuda, } \\
1965\end{array}$ & Vertex & $\begin{array}{l}\text { Coronal } \\
\text { stem of } \\
\text { ecdysial } \\
\text { cleavage } \\
\text { line }\end{array}$ & $\begin{array}{c}\text { Ecdysial } \\
\text { cleavage line }\end{array}$ & \multicolumn{2}{|c|}{ Frons } & \begin{tabular}{|c|} 
Transfrontal \\
suture (in \\
Furloroidea \\
- epistomal \\
suture) \\
\end{tabular} & $\begin{array}{l}\text { Fronto- } \\
\text { clypeus }\end{array}$ & Clypeus & $\begin{array}{l}\text { Mandibular } \\
\text { plate or lorum } \\
\text { (composite in } \\
\text { origin) }\end{array}$ & Maxillary plate \\
\hline $\begin{array}{l}\text { Evans, 1957, } \\
1968,1973\end{array}$ & Vertex & $\begin{array}{l}\text { Coronal } \\
\text { suture }\end{array}$ & $\begin{array}{l}\text { Postfrontal } \\
\text { suture }\end{array}$ & \multicolumn{2}{|c|}{ Frons } & $\begin{array}{l}\text { Epistomal } \\
\text { suture }\end{array}$ & Postclypeus & $\begin{array}{l}\text { Ante- } \\
\text { clypeus }\end{array}$ & $\begin{array}{c}\text { Lorum } \\
\text { (clypeal } \\
\text { origin) } \\
\end{array}$ & Maxillary plate \\
\hline $\begin{array}{l}\text { Hamilton, } \\
1981\end{array}$ & Vertex & $\begin{array}{c}\text { Coronal } \\
\text { suture }\end{array}$ & Ecdysial line & Postfrons & $\begin{array}{l}\text { Part of } \\
\text { vertex }\end{array}$ & $\begin{array}{c}\text { Frontogenal } \\
\text { suture }\end{array}$ & Frons & Clypeus & Lorum & $\begin{array}{c}\text { Maxillary } \\
\text { stipial lobe }\end{array}$ \\
\hline \begin{tabular}{|l|} 
Anufriev \& \\
Emeljanov, \\
1988; Emel- \\
janov, 1995 \\
(Fulgoroidea)
\end{tabular} & $\begin{array}{c}\text { Coryphe } \\
\text { (occiput, } \\
\text { not ver- } \\
\text { tex })\end{array}$ & $\begin{array}{l}\text { Coronal } \\
\text { suture }\end{array}$ & & Frons & Metope & & Postclypeus & $\begin{array}{l}\text { Ante- } \\
\text { clypeus }\end{array}$ & Lorum & Maxillary plate \\
\hline $\begin{array}{l}\text { Kukalová- } \\
\text { Peck, } 1991\end{array}$ & Vertex & & & Frons & $\begin{array}{l}\text { Post- } \\
\text { frons }\end{array}$ & & \multicolumn{2}{|c|}{$\begin{array}{c}\text { Clipeolabrum, formed } \\
\text { by fused first pair of } \\
\text { coxopodites }\end{array}$} & & \\
\hline $\begin{array}{l}\text { Kukalová- } \\
\text { Peck, } 2008\end{array}$ & $\begin{array}{c}\text { Postfrons } \\
+ \text { vertex }\end{array}$ & & & \begin{tabular}{|c|} 
Tergite I + \\
Epipleuron \\
I
\end{tabular} & Frons & & \multicolumn{2}{|c|}{ Clypeus } & & \\
\hline
\end{tabular}

Aetalionidae. Aetalion nervosopunctatum Signoret, 1851, Aetalion sp., Darthula sp.

Cicadellidae:

Eurymelinae. Eurymelini: Eurymela distincta Signoret, 1850, Eurymeloides sp.; Ipoini: Katipo sp.; Pogonoscopini: Pogonoscopus lenis (Jacobi, 1909).

Idiocerinae. Populicerus laminatus (Flor, 1861), P. populi (Linnaeus, 1761), Metidiocerus elegans (Flor, 1861), Balcanocerus sp., some other unidentified species.

Austroagalloidinae. Austroagalloides sp.

Macropsinae. Several Macropsis Lewis, 1834 and Oncopsis Burmeister, 1838 species.
Megophthalminae. Megophthalmini: Megophthalmus scabripennis Edwards, 1915; Agalliini: Agallia brachyptera (Boheman, 1847), Anaceratagallia ribauti (Ossiannilsson, 1938), Agalliota quadripunctata (Provancher, 1872); Evansiolini: Evansiola kuscheli China, 1915, E. insulans Evans, 1957; Adelungiini: Adelungia calligoni Oshanin, 1908, Platyproctus sp., Achrus robustus (Lindberg, 1929); Durgulini: Durgula lycii Emeljanov, 1964 and some others.

Ulopinae. Ulopini: Ulopa reticulata (Fabricius, 1794), Neobufonaria sp.; Mesargini: Mesargus sp.; Coloborrhinini: Coloborrhis sp.; Cephalelini: Paracephaleus sp. 
Typhlocybinae. Typhlocybini: Eurhadina pulchella (Fallén, 1806), Ribautiana ulmi (Linnaeus, 1758), Edwardsiana munda (McAtee, 1926), Fagocyba douglasi (Edwards, 1878), Aguriahana germari (Zetterstedt, 1840); Erythroneurini: Erythroneura bistrata McAtee, 1920, E. corni Robinson, 1924, Eratoneura adunca (Beamer, 1932), E. lawsoni (Robinson, 1924); E. aesculi (Beamer, 1932); Dikraneurini: Dikrella cedrelae (Oman, 1937), Notus flavipennis (Zetterstedt, 1828); Alebrini: Alebra wahlbergi (Boheman, 1845); Empoascini: Kybos spp., Kyboasca bipunctata (Oshanin, 1871).

Iassinae. Iassini: Iassus lanio (Linnaeus, 1761), Batracomorphus irroratus Lewis, 1834, and some unidentified species; Krisnini: Krisna spp.; Platyjassini: Platyjassus spp.; Scarini: numerous unidentified nymphs.

Aphrodinae. Aphrodini: Aphrodes makarovi Zachvatkin, 1948, Planaphrodes bifasciata (Linnaeus, 1758), Stroggylocephalus agrestis (Fallén, 1806); Anoscopus albiger (Germar, 1821); Errhomenini: Errhomenus brachypterus Fieber, 1866; Xestocephalini: Xestocephalus pulicarius Van Duzee, 1894, Xestocephalus spp.

Myerslopiinae. Mapuchea sp., Paulianiana sp.

Ledrinae. Ledrini: Ledra aurita (Linnaeus, 1758), L. auditura Walker, 1858, Neotituria kongosana (Matsumura, 1915); Stenocotini: Stenocotis depressa (Walker, 1851); Thymbrini: few unidentified species; Xerophloeini: Xerophloea peltata Uhler, 1877, Xedreota sp.

Tartessinae. Tartessus spp., Tartessella sp.

Neobalinae. Several unidentified species.

Coelidiinae. Teruliini: Jikradia olitoria (Say, 1830); Sandersellini: Sandersellus sp.; Tinobregmini: Tinobregmus viridescens Van Duzee, 1917; Youngolidiini: Youngolidia sp.; Thagriini: Thagria fucsovenosa (Matsumura, 1914); Coelidiini: numerous unidentified species; Equeefini: Equeefa sp.; and some other unidentified species.

Evacanthinae. Evacanthini: Evacanthus interruptus (Linnaeus, 1758), E. acuminatus (Fabricius, 1794); Vangama picea Wang \& Li, 1999; Nirvanini: Pentofia sp., and several unidentified species; Pagaroniini: Friscanus friscanus (Ball, 1909), Pagaronia sp.

Portaninae. Portanus spp.

Neocoelidiinae. Neocoelidia tumidifrons Gillette \& Baker, 1895, Retrolidia sp., and several unidentified species.

Hylicinae. Wolfella spp.

Bathysmatophorinae. Bathysmatophorus shabliovskii Kusnezov, 1932, B. reuteri Sahlberg, 1871, Lystridea sp., Hylaius oregonensis (Baker, 1898).

Cicadellinae. Cicadellini: Cicadella viridis Linnaeus, 1758, Kolla atramentaria (Motschulsky, 1859), Draeculacephala spp., and numerous unidentified species; Proconiini: Oncometopia orbona (Fabricius, 1798), O. maya Schröder, 1962, Homalodisca coagulata (Say, 1832), Dichrophleps sp., Teletusa limpida (Signoret, 1855), Procandea sp., Paraulacizes irrorata (Fabricius, 1794), Raphirhinus phosphoreus (Linnaeus, 1758), Diestostemma sp., and numerous unidentified species.

Stegelytrinae. Stegelytra sp.

Nioniinae. Nionia palmeri (Van Duzee, 1891).

Deltocephalinae. More than 200 species from different tribes (see Dmitriev, 2001, 2002a, b, 2003, 2004a, b, 2006; Dietrich \& Dmitriev, 2003).

To reconstruct a hypothetical ground plan of the head of Auchenorrhyncha, as well as the directions of the head evolution, different comparisons were made. The head of Auchenorrhyncha was compared to the generalized head structure of an insect (e.g., see Snodgrass, 1935; Matsuda, 1965) and the exuviae of a cricket. The changes of the head structures were studied on both, nymphs of different instars and adults. The head of Auchenorrhyncha was compared to the insect ground plan including the ground plan of Permian Diaphanopterodea, which had the piercing and sucking mouth parts (KukalováPeck, 1985, 1987, 1991, 1992, 2008, and Fig. 2). Finally, the phylogenetic relationships among Membracoidea were taken into account (Dietrich et al., 2001). Posterior surface and the internal structure of the head capsule have not been studied.

\section{List of terms and abbreviations}

$a$ - antenna; $a c$ - anteclypeus (= clypellus, after Oman, 1949); acr - anterior carina dividing head to crown and face; al - antennal ledge; am - acrometope, after Anufriev \& Emeljanov, 1988 - dorsal portion of frontoclypeus = metope; $a t$ - anterior tentorial pit; cgs - clypeogenal suture; $c l s$ - clypeal suture; $c o$ - coryphe, see $v$ - vertex; $c r$ - crown (= $m c$ - macrocoryphe, after Anufriev \& Emeljanov, 1988) - dorsal surface of head; cs - coronal suture (= epicranial stem); e - eye; el ecdysial line $(=p f s-$ postfrontal suture, epicranial arms); em eumetope, after Anufriev \& Emeljanov, 1988 - ventral portion of frontoclypeus = metope; $e r$ - impression of internal epistomal ridge; $e s$ - epistomal suture (= frontoclypeal suture); $f$ - frons; $f c$ - face - anteroventral surface of head; $f c l$ - frontoclypeus ( $=m t$ - metope, after Anufriev \& Emeljanov, 1988); $f s$ - frontal suture; $g$ - gena; $l$ - lorum (= mandibular plate, paraclypeus, jugum); $l b$ - labrum; $m o$ - median ocellus; $m p$ - maxillary plates; $m s p$ - maxillary sensory pit; $m t-$ metope, see $f c l$ - frontoclypeus; $o c$ - ocellus (ocelli); $p c$ - postclypeus; $p f$ - postfrons (= $m t-$ metope, after Anufriev \& Emeljanov, 1988); ra - remnants of original anterior carina dividing crown and face; $\mathrm{rac}-$ rudimentary anterior carina; $s c$ - secondary anterior carina; sgs - subgenal suture; $v$ - vertex (= co - coryphe, after Anufriev \& Emeljanov, 1988).

\section{RESULTS}

\section{Ground plan of Auchenorrhyncha}

The generalized head of Auchenorrhyncha (Fig. 1) is immovably attached to the pronotum and bears two large compound eyes $(e)$ and three ocelli $(o c, m o)$. The head is divided by sutures into several sclerites. One of the most important boundaries for understanding relations among higher level taxa is the transverse epistomal suture (es) continued laterally as the subgenal suture $(s g s)$. The epistomal suture is always connected with the anterior tentorial arms and marked externally by the anterior tentorial pits (at), which are positioned close to the bases of the antennae $(a)$. The epistomal suture in Auchenorrhyncha also has two small impressions which mark the position of the internal epistomal ridge (er). The medial portion of the head below the epistomal suture is the clypeus, divided by the transverse clypeal suture $(\mathrm{cls})$ into a smaller lower portion, the anteclypeus $(a c)$, and an upper larger portion, the postclypeus $(p c)$. Below the clypeus, the head is extended into the rostrum (labium) covered basally by the labrum $(l b)$. On each side, the clypeus is bordered by the lorum $(l)$. The lateral portion of the face, delimited by the lorum medially and by the subgenal suture dorsally is the maxillary plate $(\mathrm{mp})$, bearing a small sensillum usually deeply placed inside the maxillary sensory pit ( $m s p)$ and not visible externally. This sensillum may represent a remnant of the maxillary palpus (Evans, 1973). The lateral portion of the face above the subgenal suture and bearing the antenna $(a)$ is the gena $(g)$. The antenna in its plesiomorphic condition is segmented. The 


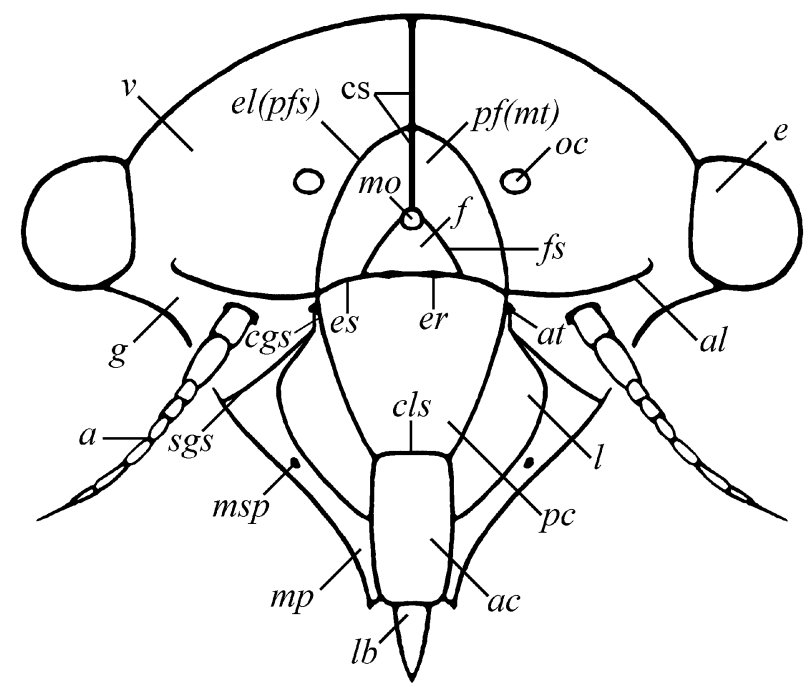

Fig. 1. Auchenorrhyncha head, ground plan, scheme.

gena is delimited dorsally by the antennal ledge $(a l)$. The small triangular area above the epistomal suture is the frons $(f)$. It is delimited dorsally by the position of the median ocellus (mo) and laterally by the frontal suture $(f s)$. The area above the frons is the postfrons ( $p f$, or metope after Anufriev \& Emeljanov, 1988, $m t$ ). The postfrons is delimited laterally by the postfrontal suture $(p f s)$ or ecdysial line $(e l)$. The large dorsal portion of the head, delimited laterally by the compound eyes $(e)$ and anteriorly by the antennal ledges and ecdysial line, is the vertex (v). The vertex and postfrons are divided medially by the coronal suture $(c s)$, reaching the frons anteriorly. The vertex bears two ocelli, which are usually placed close to the ecdysial line. During moulting, the cuticle of the head breaks forming a Y-shaped split along the coronal suture on the vertex and the ecdysial line. In adults, the ecdysial line is usually not visible.

\section{Modifications of the head structure}

In general, all sutures dividing the head sclerites are more pronounced in nymphs than in adults. The most important changes of the head relate to modification of the proportions of its main sclerites which provide characters that distinguish the main lineages of Auchenorrhyncha.

In Fulgoroidea, the head (Fig. 3E, F) in general is very similar to the ground plan (Fig. 1). It has a greatly enlarged postfrons, while the small clypeus occupies the lower portion of the face; the epistomal suture is usually distinct; the frons and median ocellus are often reduced; the ecdysial line is on the dorsum of the head. The position of the epistomal suture is confirmed by the position of the median ocellus and by two small impressions marking the position of the internal epistomal ridge; the anterior tentorial arms are apparently strongly reduced in Fulgoroidea (Bougoin, 1986a). In some Cixiidae and Delphacidae, the head has a carinate anterior margin with the carina passing in front of the ecdysial line (Fig. 4D). In this situation, the dorsal surface of the head has a complex structure: the vertex is restricted to its posterior part

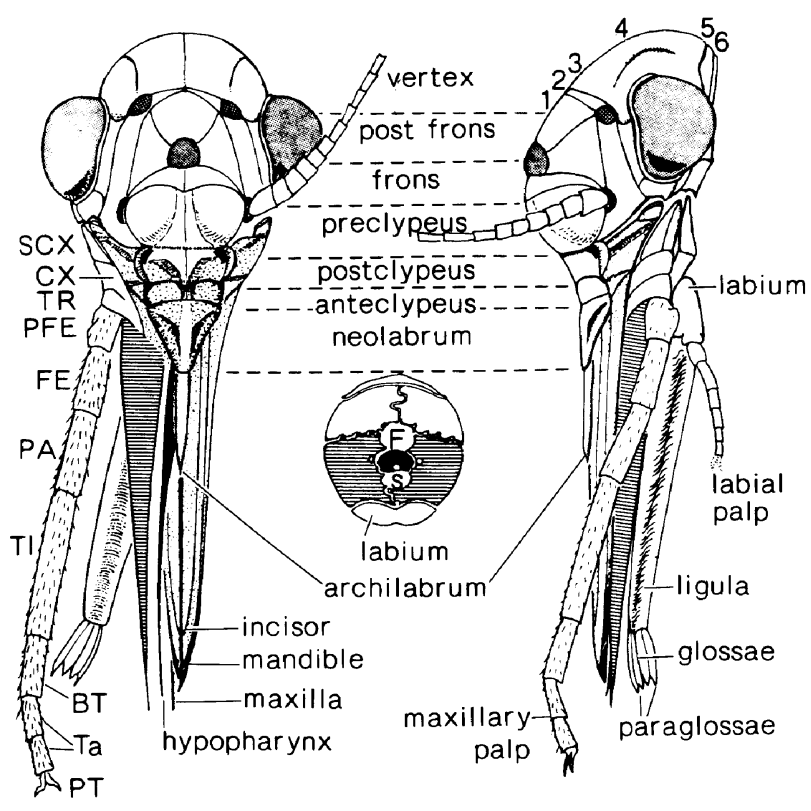

Fig. 2. Diaphanopterodea: Permuralia rodendorfi, L. Permian of Ural Mts, Russia, reconstruction of the head segmentation, anterior and lateral view (after Kukalová-Peck, 1985, 1991, used with permission).

behind the ecdysial line and a portion of the postfrons between the ecdysial line and the anterior carina occupies its anterior part. In order to emphasize the complexity of the dorsal surface of the head, it is referred to as the crown, a morphologically neutral term ( $\mathrm{cr}$, or macrocoryphe $-m c$, as suggested by Anufriev \& Emeljanov, 1988). Following the terminology of Anufriev \& Emeljanov (1988), the dorsal portion of the postfrons, may be referred to as the acrometope (am) and the lower portion as the eumetope $(\mathrm{em})$. The antenna in Fulgoroidea usually has strongly enlarged two basal segments and an annulated distal segment with a bulbous base.

In contrast to Fulgoroidea, the postfrons in Cicadoidea, Cercopoidea, and Membracoidea is a relatively small sclerite. The head of Cicadoidea (Fig. 3A, B) also resembles that of the ground plan of Auchenorrhyncha. Its main modification is that enlargement and inflation of the postclypeus pushed the epistomal suture and frons to the dorsum of the head. The frons and postfrons are distinct; the ocelli in nymphs are vestigial, but usually traceable. The anterior tentorial pits remain on the face close to the antennal bases, but the two impressions indicating the position of the internal epistomal ridge are easily visible in the middle of the epistomal suture on the dorsum of the head. The antenna is segmented entirely along its length.

The head of Cercopoidea nymphs (Fig. 3C, D) is very similar to that of Cicadoidea: the postclypeus is greatly enlarged and extends to the dorsum, the epistomal suture is distinct; however, the frontal suture is vestigial, and the median ocellus is absent. The head of Cercopoidea usually transforms significantly after moulting into the imago. From rounded, the crown-face transition becomes carinate. The rudimentary anterior carina ( $\mathrm{rac}$ ) is often traceable as a pale line on the dorsal part of the post- 

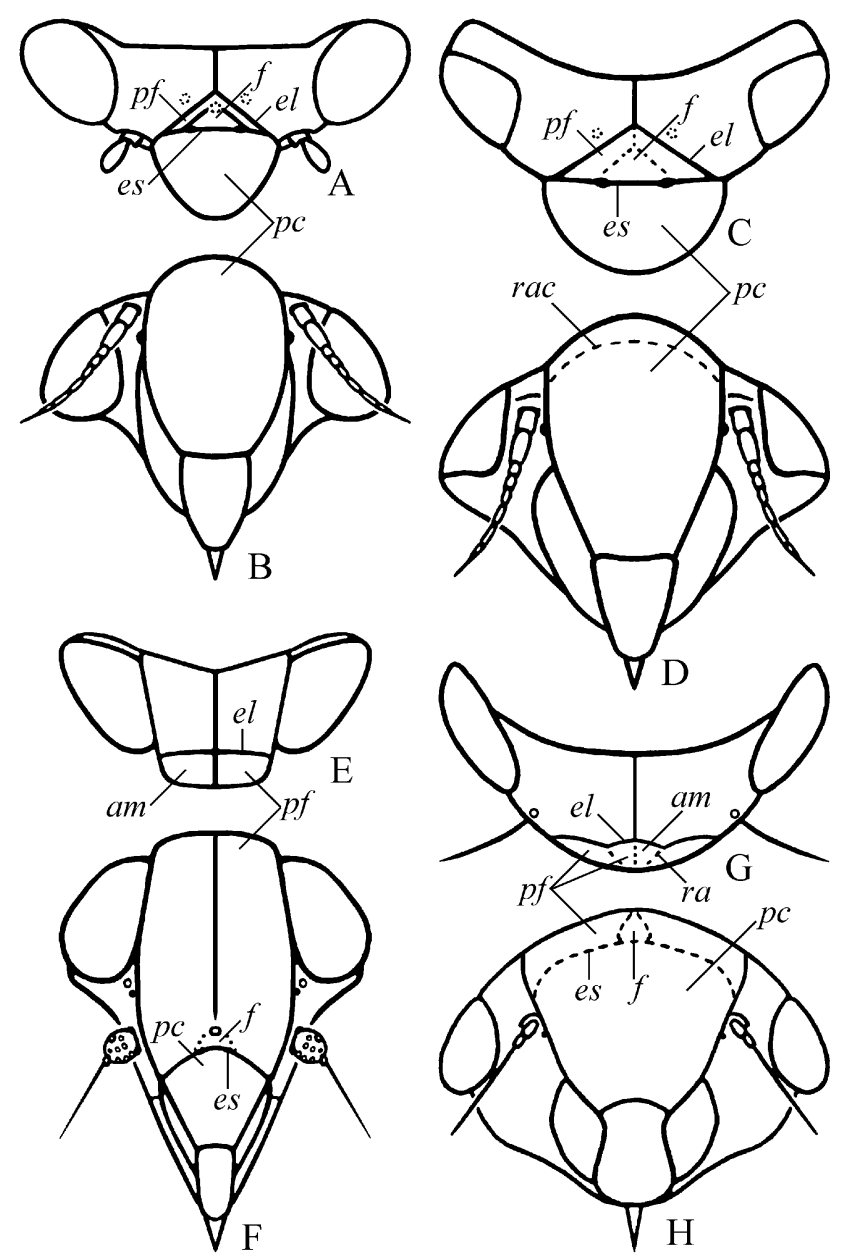

Fig. 3. Head structure of the superfamilies of Auchenorrhyncha, scheme. A - Cicadoidea, dorsal view (crown); B - same, anteroventral view (face); C - Cercopoidea, dorsal view (crown); D - same, anteroventral view (face); E - Fulgoroidea, dorsal view (crown); F - same, anteroventral view (face); $\mathrm{G}$ Membracoidea, dorsal view (crown); $\mathrm{H}$ - same, anteroventral view (face). (Remnants of sutures and rudimentary sutures are marked with dashed lines).

clypeus in nymphs (Figs 3D, 4B). After moulting, a portion of the postclypeus restricted anteriorly by the anterior carina and posteriorly by the epistomal suture becomes embedded into the crown as a distinct plate. In adults the ecdysial line is not distinct and Evans (1968) incorrectly interpreted the dorsal part of the postclypeus of Cercopidae as the frons. The antenna is segmented entirely along its length in nymphs, but the flagellum loses its segmentation in adults.

In Membracoidea nymphs (Fig. 3G, H), the epistomal suture and the frons are reduced, but in many groups they are still traceable by paler pigmentation (Figs 12B, 13B, D) and sometimes by an impression in the cuticle (Figs 5B, 6C, 9D, F). In two groups, Hylicinae and Proconiini, the frons is often extended into a long process (Fig. 11A-D), which may be absent in adults. In Membracoidea, the epistomal suture is always on the face (Figs 5-13). The postclypeus occupies a large portion of the face and, excepting Hylicinae and some Proconiini (Cicadellinae), is fused with the frons and postfrons to form the frontoclypeus $(f c l)$. The antenna is usually annulated, but in Myerslopinae, it is segmented throughout its length (Fig. 9B), and in many groups (Ledrinae, Batysmatophorinae, Aphrodinae, and some others), the antennae are segmented basally (Fig. 11H). The ecdysial line and ocelli may be on the face or on the crown.

The head similar to the ground plan, with a rounded crown-face transition, remains only in a few groups of Membracoidea, in particular, Membracidae, Aetalionidae (part), some Agalliini (Megophthalminae); Macropsinae, Eurymelinae, Idiocerinae, Iassinae (part), and Xestocephalini (Aphrodinae) (Figs 4E, 6A, C, 7E, F, 8B). In other groups, the head is modified by the development of an anterior carina, which apparently was gained and lost multiple times within Membracoidea.

Nymphs of Coloborrhinini (Ulopinae) and some Membracidae have a rounded frontoclypeus, and the strongly enlarged antennal ledges forming a bilobed anterior head margin, such that a portion of the frontoclypeus is bent onto the crown (Figs 4I, 6F, G).

Nymphs of Aetalionidae, Typhlocybinae, Ulopinae (except for Coloborrhinini), Megophthalminae (Megophthalmini, Adelungiini, and some Agalliini) have a transverse carina above the ecdysial line (Figs 4C, F, 5, $6 \mathrm{D}, \mathrm{E}, \mathrm{H}, \mathrm{I}, 7 \mathrm{~A}, \mathrm{~B}, \mathrm{G}-\mathrm{J}, 8 \mathrm{~A})$. In this case, the anterior margin of the head is often straight or bilobed. In the case of Megophthalmini, nymphs have two anterior carinae, one tracing the ecdysial line and another one above this line (Fig. 7A, B). The anterior carina is often absent in adults.

In some Megophthalminae (Megophthalmini, Durgulini, Evansiolini), Aphrodinae (Aphrodini, Xestocephalini), and Iassinae (Platyjassini, Scarini), the carina passes along or very close to the ecdysial line (Figs 4G, $7 \mathrm{~A}-\mathrm{D}, 8 \mathrm{C}-\mathrm{E})$.

Many groups of leafhoppers, such as Errhomenini (Aphrodinae), Myerslopiinae, Coelidiinae, Ledrinae, Tartessinae, Evacanthinae, Portaninae, Neocoelidiinae, Hylicinae, and some Deltocephalinae, have a transverse carina below the ecdysial line but above the frons and epistomal suture (Figs 4H, 8F, 9, 10, 11A, B, 12). This is very similar to Fulgoroidea, in which the postfrons is divided into two parts by a transverse carina (Figs 3E, F, $4 \mathrm{D})$. The portion of the postfrons above the anterior carina may be referred to as the acrometope. The presence of the acrometope is an important character for distinguishing leafhopper subfamilies, although in some, especially pale colored specimens, it is not always easy to see. In nymphs of Cicadellinae, Bathysmatophorini, Neobalinae, some Deltocephalinae (e.g. Athysanini, Goniagnathini, Macrostelini), and Nioniinae, the crown-face transition became secondarily rounded, but usually retains distinct traces of the anterior carina and acrometope (Figs 3G, H, 4K, 11C-H, 13A-D, I). In some Deltocephalinae, the head is secondarily carinate, usually with distinct traces of the original carina. In Drakensbergenini and Chiasmini, the secondary carina is situated anterad of the primary one, with a distinct triangular acrometope on the dorsal side of the flattened head and two postfrontal scler- 

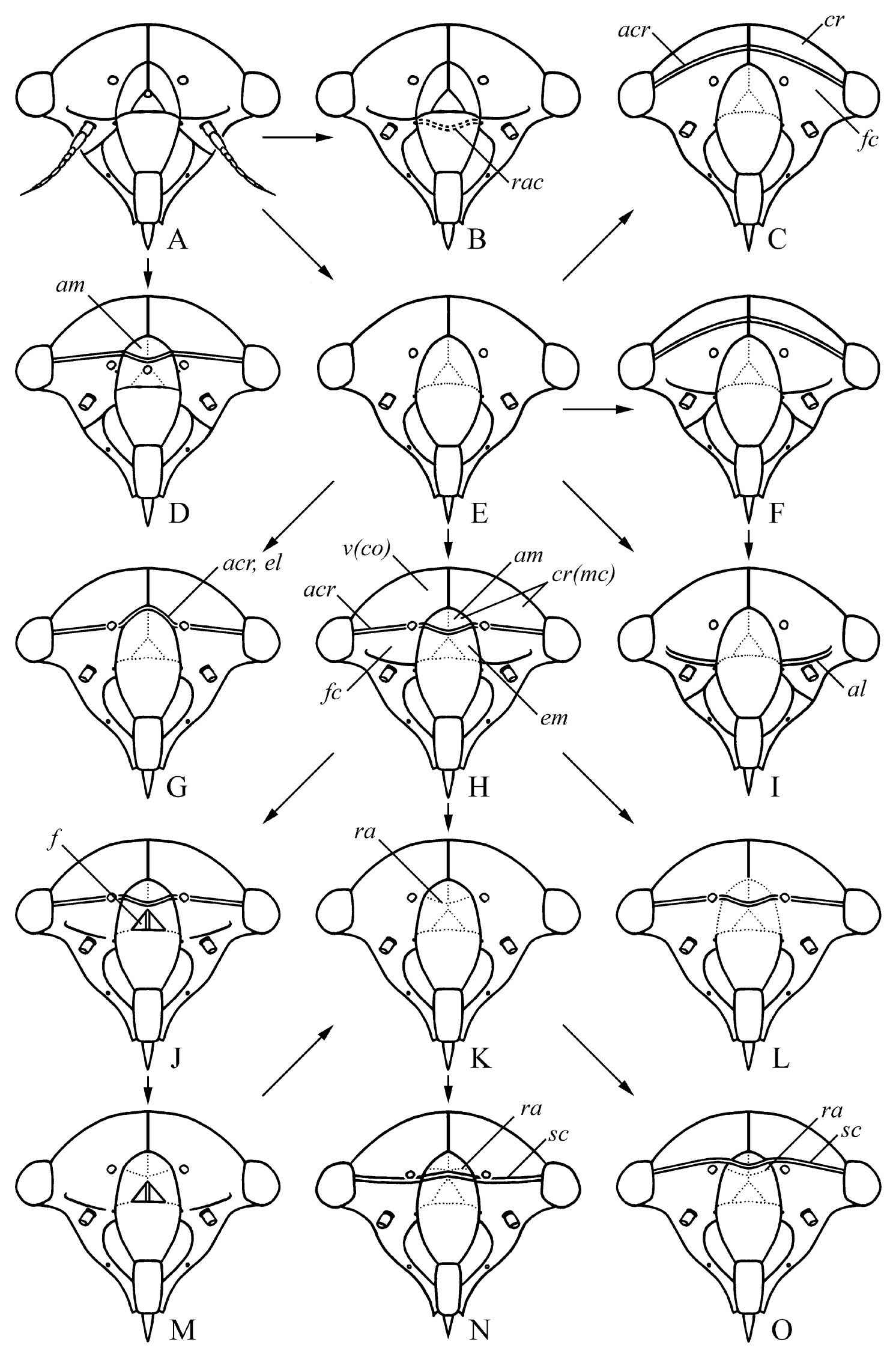

Fig. 4. Schematic modifications of the head structure. A - ground plan; B - Cercopoidea; C - Megophthalminae; D - Fulgoroidea; E - Macropsinae; F - Ulopinae, Ulopini; G - Aphrodinae, Aphrodini; H - Neocoelidiinae; I - Ulopinae, Coloborrhinini; J - Hylicinae; K - Cicadellinae, Cicadellini; L - Ledrinae, Ledrini; M - Cicadellinae, Proconiini; N - Deltocephalini, Chiasmini; O - Deltocephalinae, Koebelini, Kobeliina. (Remnants of suture are marked with dotted lines). 

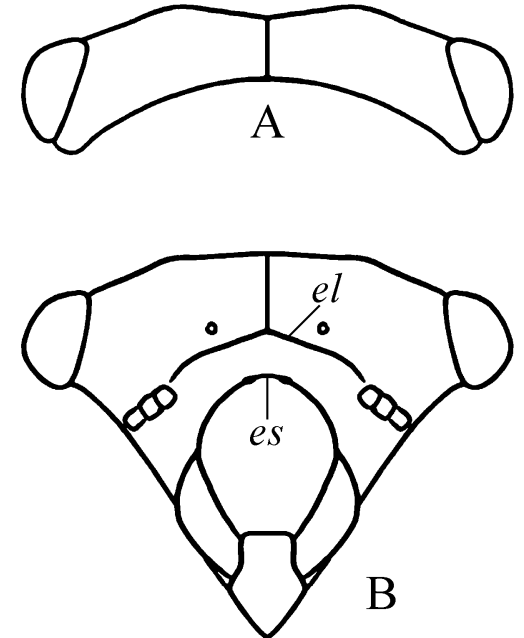

Fig. 5. Head of Aetalionidae. A - Aetalion nervosopunctatum Signoret, dorsal view (crown); B - same, anteroventral view (face).

ites laterad of it (Figs 4N, 13G, H). In Koebeliina (Deltocephalinae, Koebeliini), on the other hand, the secondary carina is above the primary one, so that the original acrometope is divided by the anterior carina into two parts, visible on the dorsal and ventral sides of the head anterior margin (Figs 4O, 13E, F).

Besides the transverse carina, many groups of leafhoppers, similarly to Fulgoroidea, have a median longitudinal carina on the crown and/or on the face, complete or incomplete (e.g., Coelidiinae, Evacanthinae, and some Deltocephalinae) (Figs 7J, 8F, 9B, 10A, B, H, 12F-H, K). The crown of nymphs in some leafhoppers may be elevated and separated from the eyes by lateral carinae (Coelidiinae, Neocoelidiinae, Evacanthinae, Portaninae) (Fig. 10). The gena of Coelidiinae often has a longitudinal carina separating the frontoclypeus from the eye (Fig. 10B).

The subgenal suture is well developed in only one subfamily of leafhoppers, Ulopinae (Figs 4F, I, 6E, G, I). The median ocellus is absent; the position of the two other ocelli, if they are present, usually correlates with the position of the ecdysial line. The ecdysial line is not always well visible in leafhopper nymphs, but nymphal exuviae may provide additional information. The ecdysial line laterally may terminate at the postclypeus or reach the antennal ledges. During moulting, the cuticle of the head may or may not break along the ecdysial line; in Ledrini (Ledrinae), the ecdysial line is completely reduced and the cuticle breaks apparently in some random position (Figs 4L, 9D).
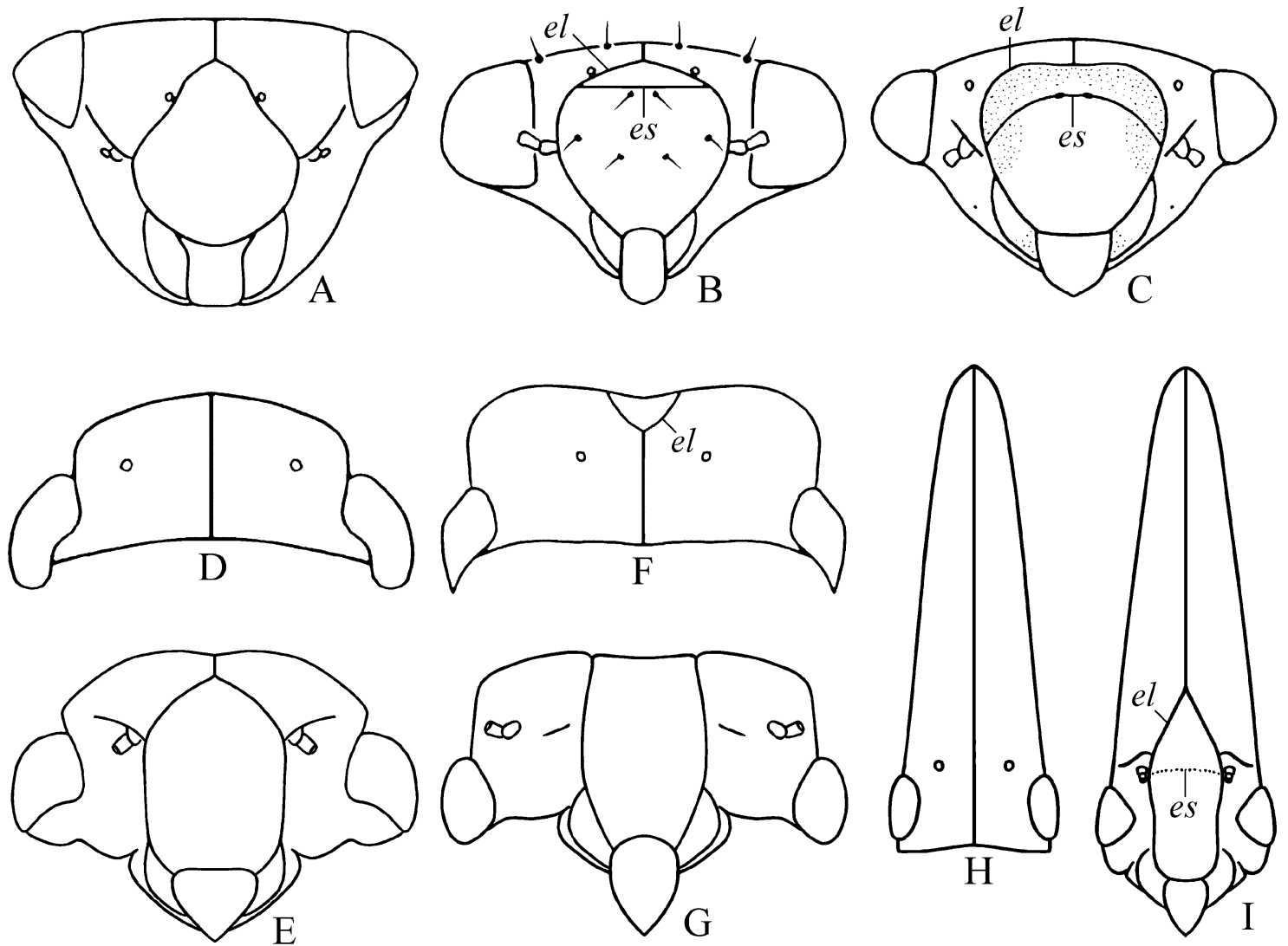

Fig. 6. Heads of leafhoppers. A - Eurymelinae: Eurymela distincta Signoret, anteroventral view (face); B - Austroagalloidinae: Austroagalloides sp., anteroventral view (face); C - Macropsinae: Oncopsis planiscuta (Thomson), anteroventral view (face); D-I Ulopinae; D - Ulopini: Ulopa reticulata (Fabricius), dorsal view (crown); E - same, anteroventral view (face); F - Coloborrhinini: Coloborrhis sp., dorsal view (crown); G - same, anteroventral view (face); H - Cephalelini: Paracephaleus sp., dorsal view (crown); I - same, anteroventral view (face). 

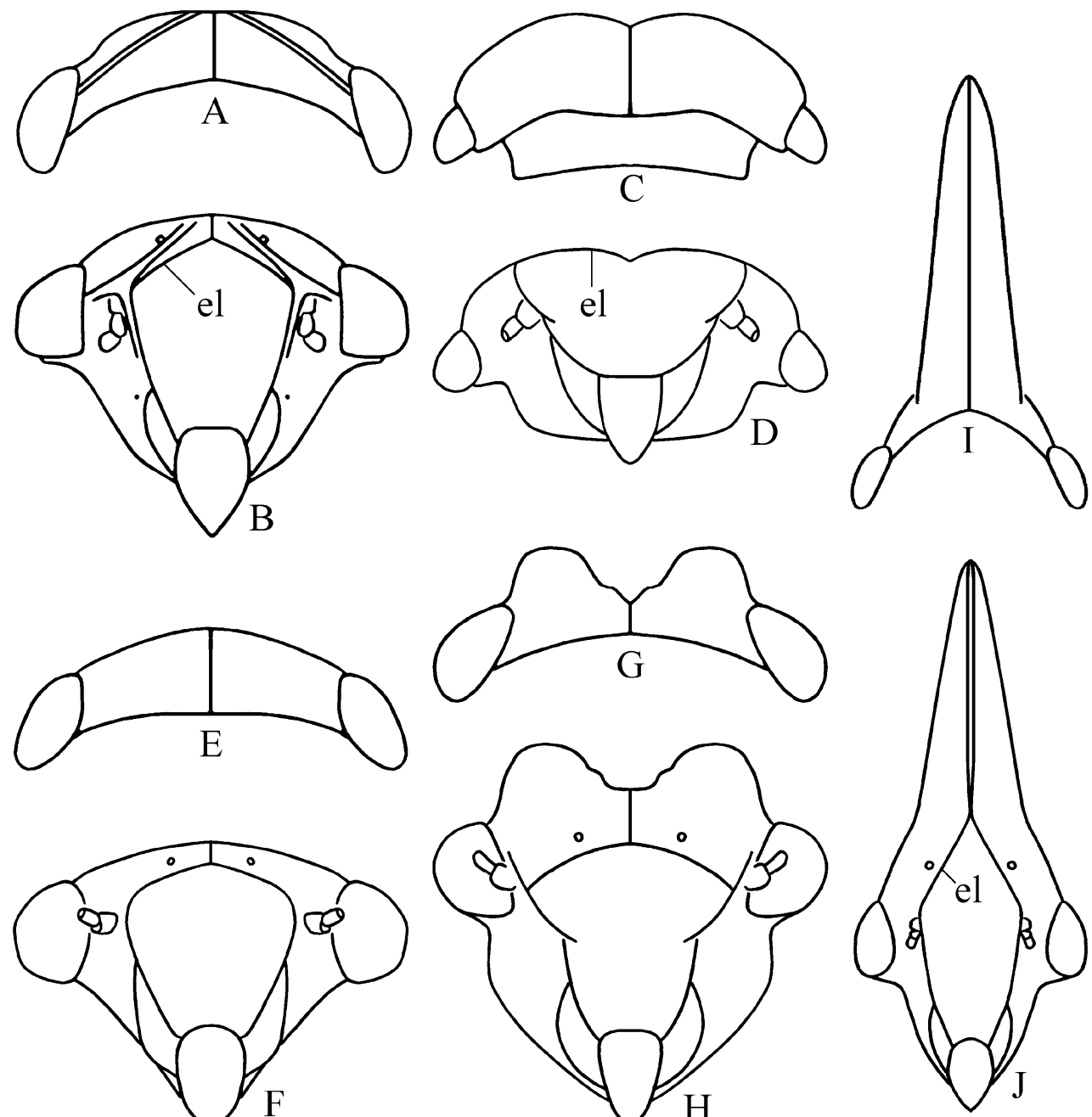

Fig. 7. Heads of leafhoppers. A-J - Megophthalminae; A - Megophthalmini: Megophthalmus scabripennis Edwards, dorsal view (crown); B - same, anteroventral view (face); C - Evansiolini: Evansiola kuscheli China, dorsal view (crown and pronotum); D same, anteroventral view (face); E-H - Agalliini; E - Agallia brachyptera (Boheman), dorsal view (crown); F - same, anteroventral view (face); G - Agalliota quadripunctata (Provancher), dorsal view (crown); H - same, anteroventral view (face); I - Adelungiini: Adelungia calligoni Oshanin, dorsal view (crown); J - same, anteroventral view (face).

The head of nymphs of many groups of leafhoppers (Cephalelini (Ulopinae), Evacanthinae, Dorycephalini (Deltocephalinae), and others), like the head of Fulgoroidea (e.g., Dictyopharidae, Fulgoridae, some Delphacidae), may became extremely elongate (Figs 6H, I, 7I, J, $12 \mathrm{C}-\mathrm{K}, 13 \mathrm{G})$, but usually, all parts of the head become proportionally expanded. Nymphs of Hylicinae and Proconiini (Cicadellinae) often have a head with an elongated apical process originating from the frons (Figs 4J, $\mathrm{M}, 11 \mathrm{~A}-\mathrm{D})$. In the groups with an elongated head it is not uncommon for nymphs possessing long heads to develop into adults with short heads [e.g., Proconiini (Cicadellinae), Drabescini (Deltocephalinae)].

\section{Notes on heads of Membracoidea nymphs \\ Superfamily MEMBRACOIDEA}

Family MEMBRACIDAE

The head has a short crown and rounded crown-face transition; the acrometope is not developed (Fig. 4E). The ecdysial line is usually on the face. In some genera, the antennal ledges are strongly enlarged and form the anterior margin of the crown, in which case the ecdysial line is on the dorsal surface of the head similar to Coloborrhinini (Ulopinae) (Figs 4I, 6F, G).

\section{Family AETALIONIDAE}

The head is similar to that of Membracidae, but usually has a transverse carina above the ecdysial line (Figs 4C, 5). The ecdysial line has long arms terminated at the bases of the antennae. The epistomal suture is usually well developed. The ocelli are on the face above the ecdysial line. The crown is short and broad.

\section{Family CICADELLIDAE}

Subfamily Eurymelinae

The crown is broad, with a broadly rounded anterior margin subparallel to the posterior margin. The crownface transition is broadly rounded, without a transverse carina; the acrometope is not developed (Figs 4E, 6A). The ecdysial line forms a sharp angle. The epistomal 

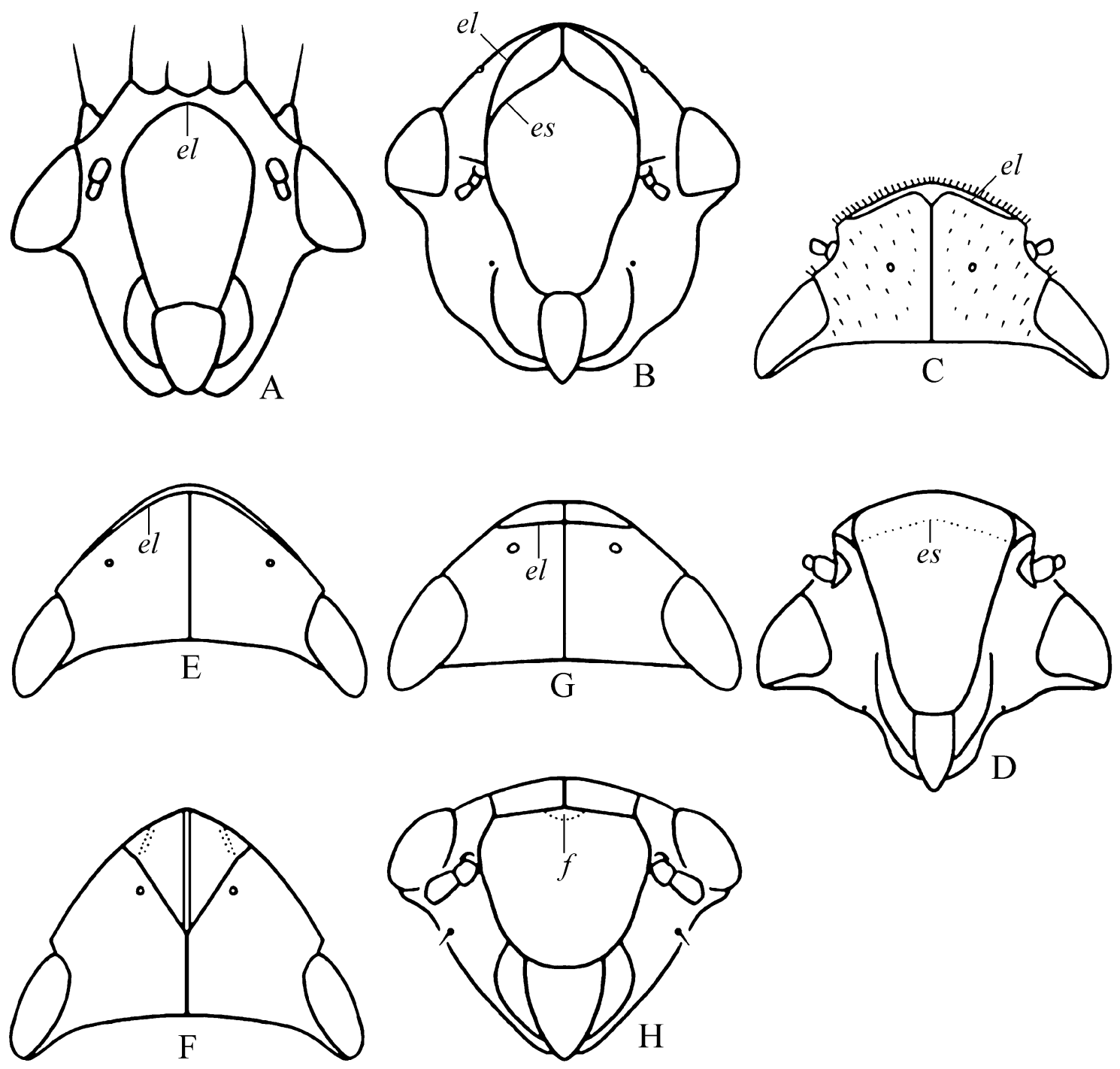

Fig. 8. Heads of leafhoppers. A - Typhlocybinae, Typhlocybini: Eurhadina pulchella (Fallén), anteroventral view (face); B-D Iassinae; B - Krisnini: Krisna sp., anteroventral view (face); C - Scarini: unidentified nymph, dorsal view (crown); D - same, anteroventral view (face); E-H - Aphrodinae; E - Aphrodini: Aphrodes makarovi Zachvatkin, dorsal view (crown); F Errhomenini, Errhomenus brachypterus Fieber, dorsal view (crown); G - Xestocephalini: Xestocephalus sp., dorsal view (crown); H - same, anteroventral view (face).

suture is not traceable. The maxillary sensory pit is on the lowermost part of the maxillary plate.

\section{Subfamily Idiocerinae}

The head is similar to that of Eurymelinae (Fig. 4E), but with an obtuse angle formed by the ecdysial line. In some species the epistomal suture is well developed.

\section{Subfamily Austroagalloidinae}

The head is similar to that of Eurymelinae (Figs 4E, 6B). The epistomal suture is well developed and slightly carinate; in adults, this carina is absent, but a new carina behind the ecdysial line is developed. The maxillary sensory pit is on the posterior surface.

\section{Subfamily Macropsinae}

The crown is broad, with a widely rounded anterior margin subparallel to the posterior margin. The crownface transition is broadly rounded, without a transverse carina; the acrometope is not developed. The epistomal suture is traceable in some species, it is slightly discolored, and there are often two impressions in the middle of the frontoclypeus (Figs 4E, 6C).

\section{Subfamily Megophthalminae}

The crown has a rounded, straight, or bilobed anterior margin; rarely the head is produced (some Adelungiini) (Fig. 7I, J). The crown-face transition is rounded (Figs $4 \mathrm{E}, 7 \mathrm{E}, \mathrm{F}$ ) or carinate, in which case the ecdysial line is on the face (Adelungiini, Megophthalmini, and some Agalliini) (Figs 4C, 7A, B, G-J), or the ecdysial line traces the anterior carina (Evansiolini and Durgulini) (Figs 4G, 7C, D). The acrometope is absent. The ocelli, if present, are on the face.

\section{Subfamily Ulopinae}

The crown is usually wider than long, but in Cephalelini, the head is strongly elongated (Fig. 6H, I). 

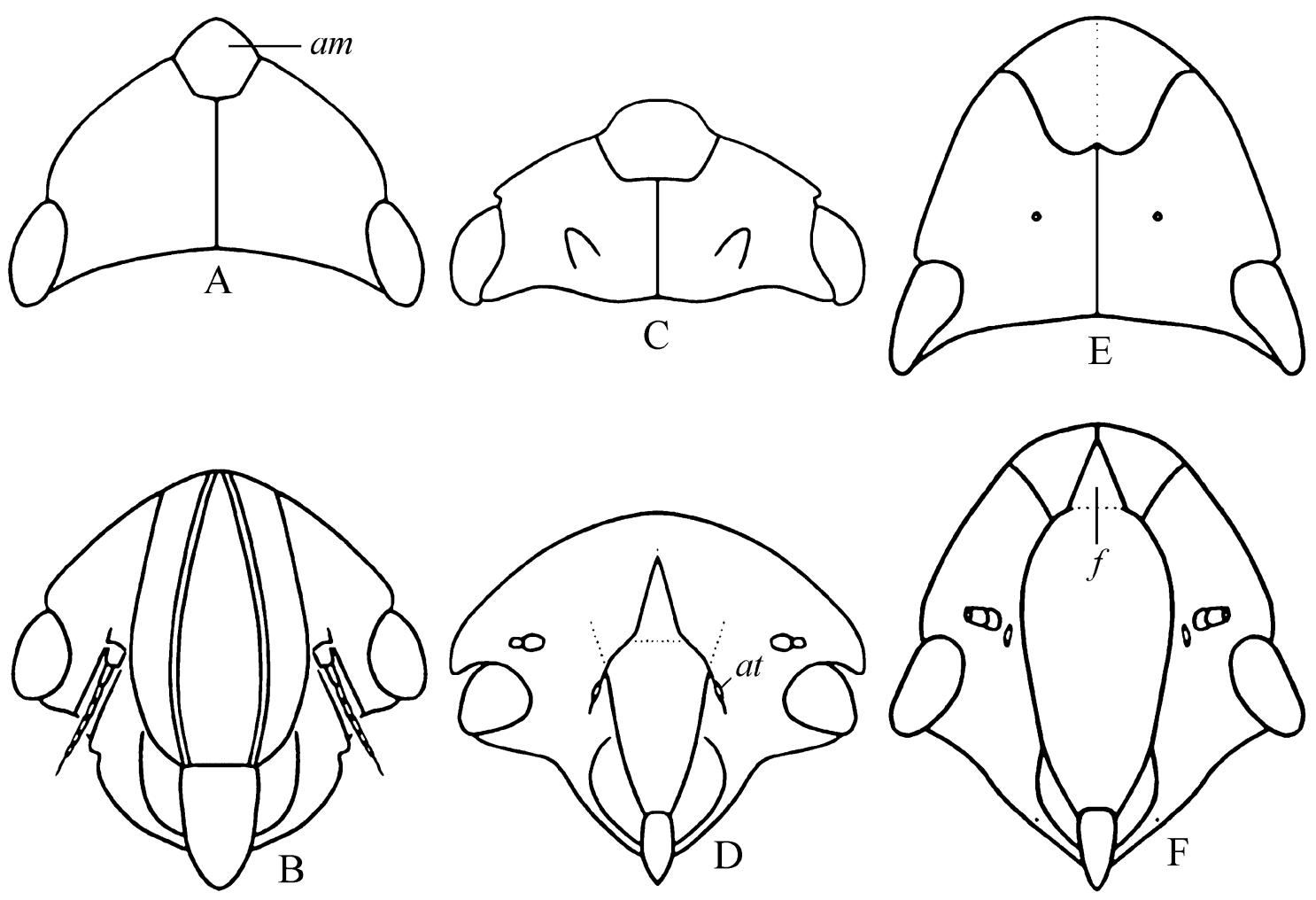

Fig. 9. Heads of leafhoppers. A - Myerslopiinae: Paulianiana sp., dorsal view (crown); B - same, anteroventral view (face); C Mapuchea sp., dorsal view (crown); D-F - Ledrinae; D - Ledrini: Ledra aurita (Linnaeus), anteroventral view (face); E - Xerophloeini: Xerophloea peltata Uhler, dorsal view (crown); F - same, anteroventral view (face).

The transition to the face is usually carinate with the ecdysial line below this carina (Figs 4F, 6D, E, H, I); the acrometope is not developed. In Coloborrhinini, the transverse carina is not developed, instead, the antennal ledges are strongly enlarged and forming the anterior margin of the crown, in which case the ecdysial line is on the dorsal side of the head (Figs 4I, 6F, G). The ocelli are on the crown, distant from the eyes. The subgenal suture is well developed.

\section{Subfamily Typhlocybinae}

The head has a rounded or often quadrate or bilobed anterior margin; the crown-face transition is carinate, with the ecdysial line on the face; the acrometope is not developed (Figs 4C, 8A). The ocelli, if present, are on the face. The face is usually considerably longer than wide.

\section{Subfamily Iassinae}

The crown varies in shape; the transition to the face is rounded (primary, without traces of the original carina) (Fig. 4E) or carinate with the ecdysial line mostly on the face (Figs 4C, 8B), or only slightly extending onto the crown (Scarini) (Figs 4G, 8C, D). When the crown-face transition is carinate, the ocelli are placed on the crown; if it is rounded, the ocelli are at the fore margin of the head; in both cases, the ocelli are distant from the eyes.

\section{Subfamily Aphrodinae}

The crown has a rounded or angulate anterior margin, about as long as wide or wider. The head of Aphrodini and Xestocephalini has a rounded or carinate crown-face transition, with the ecdysial line usually slightly above and tracing this carina (Figs $4 \mathrm{E}, \mathrm{G}, 8 \mathrm{E}, \mathrm{G}, \mathrm{H}$ ); in Errhomenini, the crown-face transition is strongly carinate; the acrometope is well developed, and the ecdysial line forms a sharp angle on the crown (Figs 4H, 8F). The ocelli are at the fore margin of the head (in Aphrodini and Xestocephalini) or on the crown (in Errhomenini).

\section{Subfamily Myerslopiinae}

The crown is wider than long, with a slightly produced anterior margin and carinate transition to face; the ecdysial line is on the crown, and the acrometope is distinct (Figs 4H, 9A-C). The ocelli are absent. The antennae are segmented along their length, in Paulianiana Evans, 1953, they are placed into longitudinal grooves on the genae (Fig. 9A, B). The epistomal suture is not visible; the frontoclypeus often has longitudinal carinae. The maxillary sensory pit is on the posterior surface of the maxillary plate.

Note. The genus Paulianiana was placed by Hamilton (1999) in the tribe Sagmatiini (Euacanthellinae). Based on combination of nymphal and adult characters (segmented antennae, enlarged meron of mesocoxa, two rows of laterotergites, etc.), it seems reasonable to keep Paulianiana in Myerslopiinae as it was previously suggested by Evans (1953).

\section{Subfamily Ledrinae}

The head is produced, usually as long as wide or longer; the crown-face transition is carinate, with the ecdysial line on the crown (Figs 4H, 9E, F); in Ledrini, 

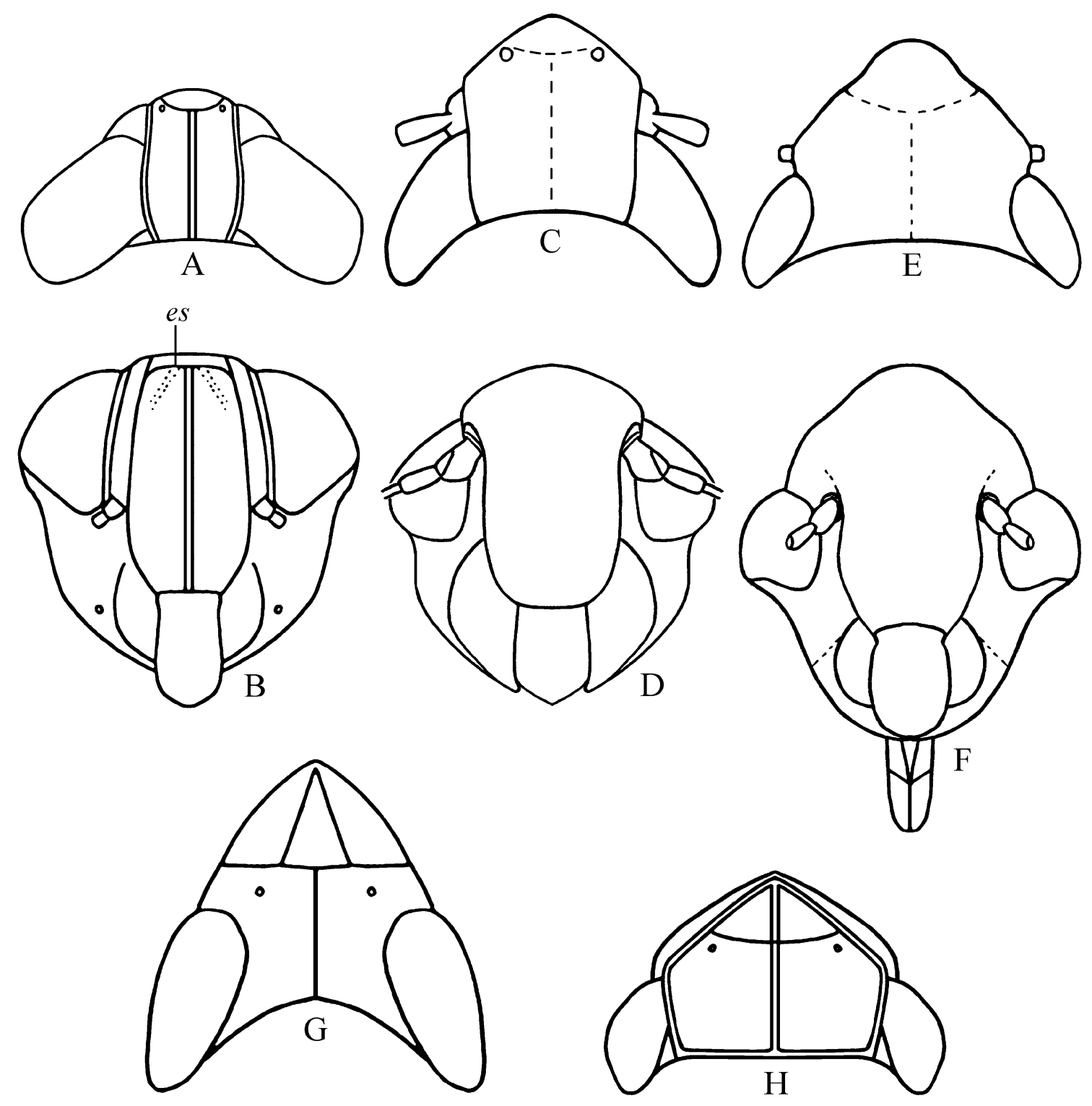

Fig. 10. Heads of leafhoppers. A - Coelidiinae: Teruliini: Jikradia olitoria (Say), dorsal view (crown); B - same, anteroventral view (face); C - Portaninae: Portanus sp., dorsal view (crown); D - same, anteroventral view (face); E - Neocoelidiinae: Neocoelidia tumidifrons Gillette \& Baker, dorsal view (crown); F - same, anteroventral view (face); G - Coelidiinae: Equeefini: Equeefa sp., dorsal view (crown); H - Evacanthinae: Evacanthini: Evacanthus acuminatus (F.), dorsal view (crown).

the ecdysial line is reduced and not traceable; when molting, the cuticle breaks in various places (Figs 4L, 9D). The ocelli are on the crown, distant from the eyes. The frons and the frontal suture in Ledrinae are distinct; this led Wagner (1951) to incorrectly interpret the head of Ledra Fabricius, 1803 as having the ecdysial line on the face.

\section{Subfamily Tartessinae}

The crown is variable in shape, with rounded or produced anterior margin. The transition to the face is carinate, with the ecdysial line on the crown, or secondarily rounded; the acrometope is distinct (Fig. 4H, K). The ocelli are on the crown, distant from the eyes.

\section{Subfamily Neobalinae}

The crown is broad, with the anterior margin subparallel to the posterior margin or weakly produced. The transition to the face is secondarily rounded; the acrometope is distinct (Fig. 4K). The ocelli sit close to the anterior margin of the head, distant from the eyes.

\section{Subfamily Coelidiinae}

The eyes are usually enlarged. The crown is elevated above the eyes, with a rounded or (rarely) produced anterior margin. The ocelli are on the crown, distant from the anterior margin. The crown-face transition is carinate or secondarily rounded; the acrometope is distinct (Figs $4 \mathrm{H}$, $10 \mathrm{~A}, \mathrm{~B})$. The crown and frontoclypeus often have a median longitudinal carina (Fig. 10A, B). The antenna socket is near the lower margin of the eye. The gena often has a carina separating the frontoclypeus from the eye 


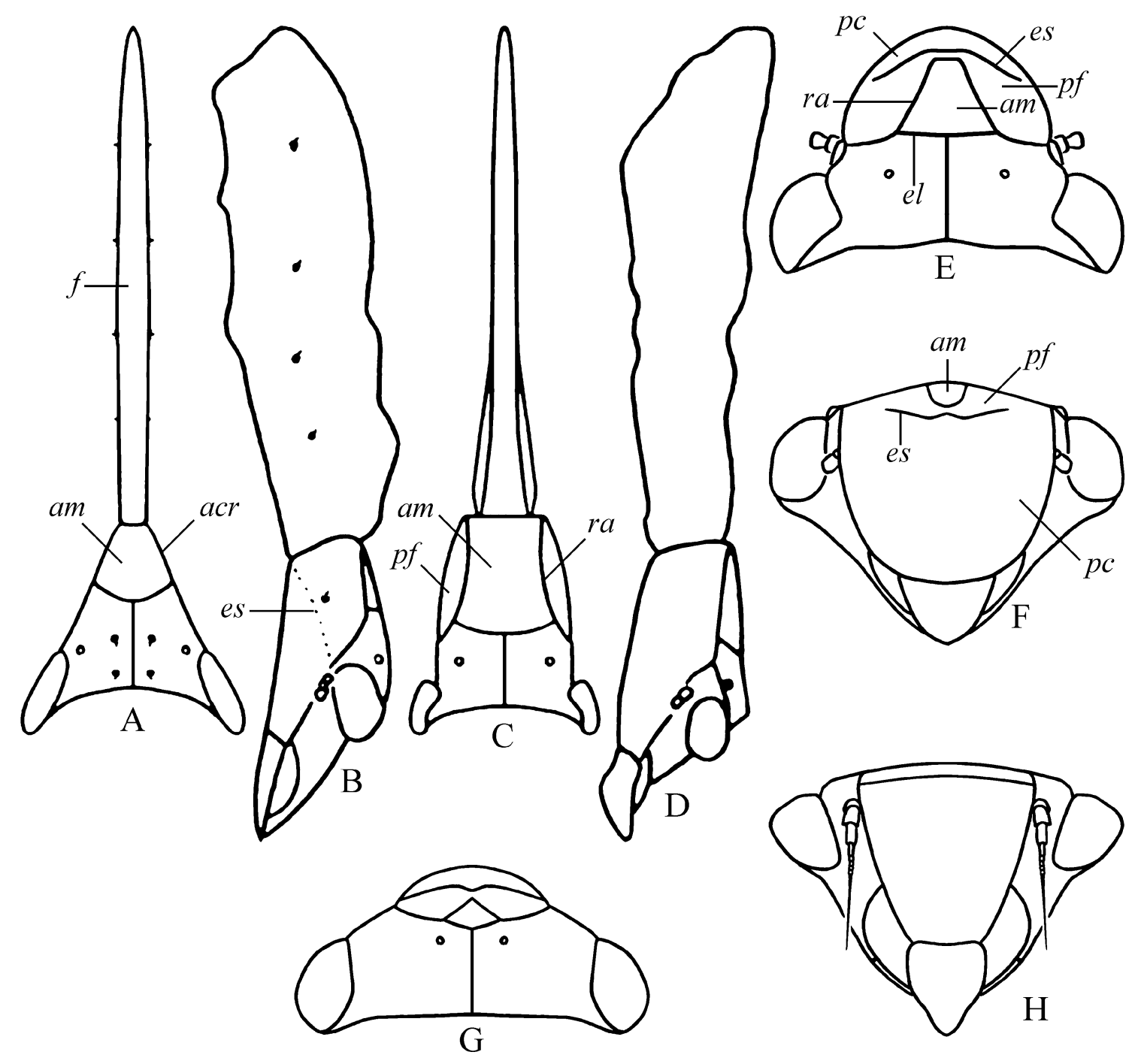

Fig. 11. Heads of leafhoppers. A - Hylicinae: Wolfella sp., dorsal view (crown); B - same, head, lateral view; C-F - Cicadellinae; C - Proconiini: Diestostemma sp., dorsal view (crown); D - same, head, lateral view; E - Oncometopia maya Schroeder, dorsal view (crown); F - same, anteroventral view (face); G - Bathysmatophorinae: Bathysmatophorus shabliovskii Kusnezov, dorsal view (crown); $\mathrm{H}$ - same, anteroventral view (face).

(Fig. 10B). Nymphs of the tribe Equeefini, while sharing some features of Coelidiinae (the large eyes and the low position of the antennae), have the crown-face transition rounded, and a long and narrow acrometope, with the traces of the original carina on the dorsal side of the head (Figs 4K, 10G), which is characteristic for Bathysmatophorinae, Cicadellinae, and some Deltocephalinae (Figs 11E-H, 13A-C, I).

\section{Subfamily Evacanthinae}

The crown is usually elevated above the eyes, about as long as wide or distinctly elongated, with an angulate anterior margin. The crown-face transition is usually carinate, with the ecdysial line on the dorsal surface; the acrometope is present (Figs $4 \mathrm{H}, 10 \mathrm{H}$ ). The ocelli are on the dorsum of the head, distant from the margin. The antennae are often attached near the anteroventral margin of the eyes. The strongly elongated head of Vangama Distant, 1908, is morphologically similar to that of Dorycephalini and Eupelicini (Deltocephalinae) (Fig. 12I).

\section{Subfamily Portaninae}

The crown is longer than wide, slightly elevated above the eye, with long parallel lateral margins and an angulate anterior margin. The crown-face transition is carinate or narrowly rounded; the ecdysial line is on the dorsal side of the head; the acrometope is distinct (Figs 4H, 10C, D). The antenna is attached near the dorsal margin of the eye, very long.

\section{Subfamily Neocoelidiinae}

The crown is as long as wide or longer, elevated above the eyes, with an angulate anterior margin. The crownface transition is carinate; the ecdysial line is on the crown; the acrometope is distinct (Figs 4H, 10E, F). The ocelli are at the anterior margin of the head, close to the eyes. The antenna is long, attached near the medium level of the eye. 

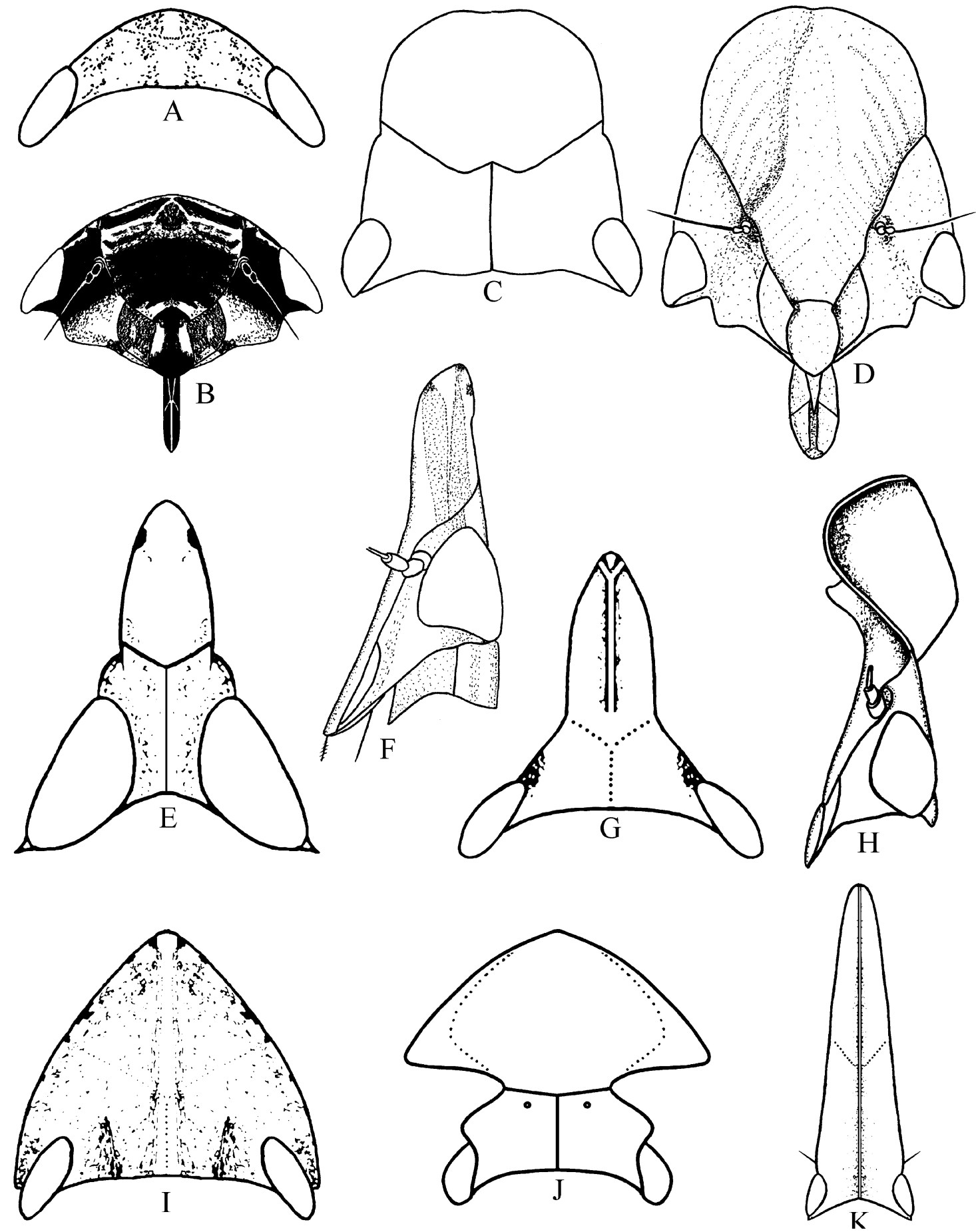

Fig. 12. Heads of leafhoppers. A-K - Deltocephalinae; A - Selenocephalini: Selenocephalus obsoletus (Germar, 1817), dorsal view (crown); B - Selenocephalus pallidus Kirschbaum, 1868, anteroventral view (face); C - Helalini: Glossocratus foveolatus Fieber, 1866, dorsal view (crown); D - same, anteroventral view (face); E - Scaphytopiini: Stymphalus rubrostriatus (Horváth, 1907), dorsal view (crown); F - same, lateral view; G - Drabescini: Drabescus ineffectus (Walker, 1858), dorsal view (crown); H - same, lateral view; I - Eupelicini: Eupelix cuspidata (Fabricius), dorsal view (crown); J - Listrophorini: Listrophora evansi Boulard, 1971, dorsal view (crown); K - Paradorydiini: Paradorydium lanceolatum (Burmeister, 1839), dorsal view (crown).

\section{Subfamily Hylicinae}

The head is elongate; the frons is enlarged and extended into a long apical process (Figs 4J, M, 11A, B). The crown-face transition is carinate or rounded with traces of the original carina well visible on the dorsum of the head; the ecdysial line and ocelli are on the crown.

\section{Subfamily Bathysmatophorinae}

The head is similar to that of Cicadellinae. The crown is as long as wide or wider and has a broadly rounded anterior margin. The transition to the face is broadly rounded; the acrometope is distinct (Figs 4K, 11G, H). The epistomal suture is often well visible. The ocelli are on the crown, distant from the anterior margin. 

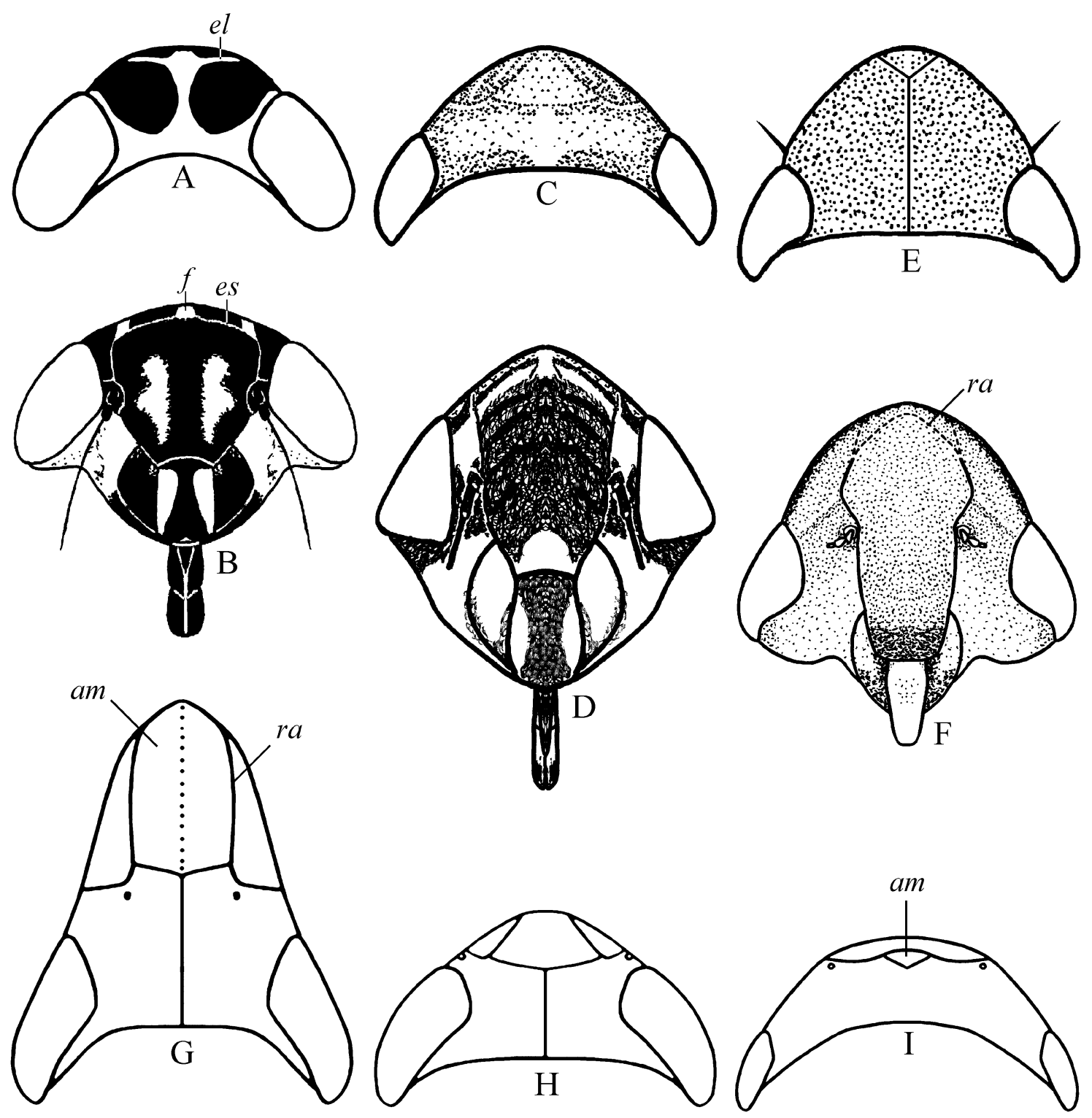

Fig. 13. Heads of leafhoppers. A-H - Deltocephalinae; A - Macrostelini: Coryphaelus gyllenhalii (Fallén, 1826), dorsal view (crown); B - same, anteroventral view (face); C - Athysanini: Handianus potanini (Melichar, 1900), dorsal view (crown); D - Athysanini: Eohardia fraudulenta (Horváth, 1903), anteroventral view (face); E - Koebeliini, Koebeliina: Koebelia grossa Ball, 1909, dorsal view (crown); F - same, anteroventral view (face); G - Drakensbergenini: Drakensbergena sp., dorsal view (crown); H - Chiasmini: Doratura stylata (Boheman, 1847), dorsal view (crown); I - Nioniinae: Nionia palmeri (Van Duzee, 1891), dorsal view (crown).

\section{Subfamily Cicadellinae}

The crown has a broadly rounded or angulate anterior margin; the ocelli are on the crown, distant from the anterior margin. The crown-face transition is rounded, often broadly rounded, with a distinct acrometope (Figs $4 \mathrm{~K}$, $11 \mathrm{E}, \mathrm{F})$. The epistomal suture is often distinct. Nymphs of some Proconiini have the enlarged frons extended into a long apical process (Figs 4M, 11C, D).

\section{Subfamily Stegelytrinae}

The head is extended, with an anterior projection apparently similar to that of Hylicinae and Proconiini (Fig. 4J, $\mathrm{M})$, but the homology is uncertain because only a single early instar nymph was available for study. The crownface transition is rounded; the ecdysial line is on the crown. The antenna is long, attached near the lower margin of the eye.

\section{Subfamily Deltocephalinae}

The head strongly varies in shape, in some groups like Hecalini, Scaphytopiini, Drabescini, Eupelicini, it may be strongly elongated, with or without a longitudinal carina (Fig. $12 \mathrm{C}-\mathrm{K}$ ). The ocelli are usually at the anterior margin of the head. The acrometope is distinct; the crown-face transition is carinate (Figs $4 \mathrm{H}, 12$ ) or secondary rounded, with distinct traces of the original carina (Figs 4K, 13A-D); in some groups, like Chiasmini, Drakensbergenini, Koebeliini, the crown-face transition may became secondarily carinate with the new carina passing below or above the original one (Figs $4 \mathrm{~N}, \mathrm{O}, 13 \mathrm{E}-\mathrm{H})$. In 
Eupelicini, the ecdysial line is poorly developed, so comparing the head of Eupelix Germar, 1821 with Ledra Fabricius, 1803 and incorrectly interpreting the latter, Wagner (1950) wrongly concluded that Eupelix also has the ecdysial line on the face.

\section{Subfamily Nioniinae}

The crown is considerably wider than long (very short in adults) with the anterior margin broadly rounded. The transition to the face is secondarily broadly rounded; the acrometope is distinct and, small (Figs 4K, 13I).

Subfamilies Mileewinae, Signoretiinae, Neopsinae, and Euacanthellinae

Nymphs of Mileewinae, Signoretiinae, Neopsinae, and Euacanthellinae were not studied.

\section{DISCUSSION}

\section{Differences in interpretation of the head homologies}

As seen in Table 1, the main problem in understanding the homologies of the head of Membracoidea is drawing the boundary between the clypeus and the frons. The two sclerites are separated by the epistomal suture, which in the traditional interpretation is marked externally by the position of the anterior tentorial pits. In Membracoidea adults, the epistomal suture usually is not visible, so the large medial portion of the face is often called the frontoclypeus $(f c l)$, indicating that the boundaries of the frons and clypeus are uncertain. The anterior tentorial pits in Auchenorrhyncha are positioned close to the bases of the antennae.

Snodgrass $(1935,1947)$ interpreted the epistomal suture as a "secondary device for strengthening the head wall". He considered the boundary between the clypeus and frons only as a functional one, suggesting that the frons is the place of attachment for the labral muscles, whereas the clypeus is the place of attachment for the dilator muscles of the cibarium and the dorsal muscles of the buccal cavity. His interpretation was based on the study of the cicada head and was leter criticized by Cook (1944); Ferris (1944), DuPorte (1962), and Matsuda (1965), who stated that although the cibarial muscles usually originate in the clypeus, they may shift to the frons or even to the vertex in response to functional requirements.

DuPorte $(1946,1962)$ studied the head of a cicada and suggested drawing a possible epistomal suture as a straight line between the tentorial pits. Doing this, he interpreted the postclypeus of cicada as the frontoclypeus and the epistomal suture (called the transfrontal sulcus) as a secondary line dividing the frons into two parts, the dorsal postfrons and the ventral antefrons.

Hamilton (1981) and Mejdalani (1998) used DuPorte's (1946, 1962) and Matsuda's (1965) interpretation of the head of Psocoptera and referred to the large sclerite of the face of Hemiptera as the frons. Matsuda (1965) used the position of the frontal ganglion as an indicator of the boundary between the clypeus and frons. Yoshizawa \& Saigusa (2003) criticized the works by DuPorte, Matsuda, and Hamilton, showing that the internal epistomal ridge is directed toward or slightly ventrad of the frontal ganglion. Using Matsuda's definition of the frons, as well as the attachment of the cibarial muscles, Yoshizava \& Saigusa (2003) concluded that the large sclerite of the face of Psocoptera, as well as Hemiptera, should be interpreted as the postclypeus.

Anufriev \& Emeljanov (1988) and Emeljanov (1995) proposed an alternative terminology for head sclerites based on the differences in distribution of the sensory pits on the nymphal head of Delphacidae and Cixiidae (Fulgoroidea). The posterior portion of the dorsum of the head which never has sensory pits was called the coryphe; the anterior portion of the dorsum of the head and a part of the face above the clypeus and frons, often having sensory pits, was referred to as the metope. The metope could secondary be divided by a transverse carina into two parts: dorsal portion, the acrometope, and ventral portion, the eumetope. The acrometope united with the coryphe forms the macrocoryphe.

After comparison of the head of Fulgoroidea with the head of leafhoppers and other insects, it was discovered, that the coryphe is the homologous structure with the vertex; the metope is homologous to the postfrons; and the macrocoryphe is homologous to the crown (Fig. 1, Table 1). The acrometope and eumetope as a secondary modification of the head capsule do not have alternative names and were retained in this paper.

Kukalová-Peck $(1985,1987,1991,1992)$ published a reconstruction of the head of the Lower Permian Permuralia rodendorfi (Diaphanopterodea) (Fig. 2) which shows the head segmentation and closely resembles the ground plan of Hemiptera (Fig. 1). The postfrons of Permuralia has a dorsal triangular sclerite interpreted by Kukalová-Peck as a tergite of the first segment of the head (the lateral portions are interpreted as epicoxae), and similar to the acrometope (see below) of Fulgoroidea and Cicadellidae. The acrometope in this paper is considered a secondary modification related to flattening of the head capsule that evolved multiple times within Auchenorrhyncha and, thus, is not homologous to the first tergite of Permuralia Sinichenkova \& Kukalová-Peck (1997).

In 2008, Kukalová-Peck published a new scheme of the generalized insect head, where she interprets the frons and postfrons as being parts of the acron, a frontal flap of a non segmental origin, which was not previously reported in Arthropoda. She also shifted the position of the frons and postfrons above the median ocellus, so that the frons, in her interpretation, corresponds to the postfrons in the Fig. 1, and the postfrons corresponds to the anterior part of the vertex. This scheme is completely different from the traditional interpretation of the head structure (DuPorte, 1946, 1962; Snodgrass, 1935, 1947; Matsuda, 1965). Kukalová-Peck did not comment on landmarks used for distinguishing the frons from the postclypeus (such as the position of the anterior tentorial pits, attachment of the dilator muscle of the cibarium, and the position of the frontal ganglion). Thus, her scheme is not adopted here because it requires further evaluation and the establishment of new criteria for separating the frons and clypeus, as well as the vertex and postfrons. 
DuPorte (1946) and Snodgrass (1947) provided evidence that the ecdysial line is just a functional line of the weakness of the cuticle, rather than a constant morphological feature. It varies within different groups of insects in the position of the fork and in the points where the arms terminate. In Auchenorrhyncha, this line is more or less constant and shifts its position reflecting to the secondary modification of the head capsule and changes in the proportions of the sclerites.

Additionally, the agreement was not achieved on the origin of the lorum (mandibular plate). Snodgrass (1935, 1947) thought that the lorum is a part of the hypopharynx and has the mandibular origin; Evans (1957, 1968, 1973, 1975 ) and Lew (1960) considered it as a separate part of the clypeus; Parsons (1964) like Snodgrass also considered the lorum as a derivative of the hypopharynx, but of a nonapendicular origin. Embriological studies (see Matsuda, 1965) suggest composite clypeal and hypopharyngial (mandibular) origin of the lorum. So, the term "mandibular plate", which is widely used in systematics of Heteroptera referring to the same structure, does not have sufficient morphological basis. For the detailed discussion of the origin of the lorum see the works of Lew (1960), Matsuda (1965), and Evans (1975); this is out of the scope of this paper, because in spite of the differences of opinions, the lorum is consistently considered as a homologous structure among different groups of Auchenorrhyncha.

The maxillary plate of Hemiptera is considered as a structure of the maxillary origin by most of the researchers, but this was doubted by Parsons (1964) and Bourgoin (1986b). They suggested a genal-postgenal non appendicular origin of the plate and that the subgenal suture, which present in some Hemiptera is not a homologous structure to the subgenal suture in other Pterygota. Evans (1973) described a sensory pit (now often referred to as the Evans' organ) as being present on the maxillary plate of leafhoppers. He interpreted it as a remnant of the maxillary palp of other insects. Bourgoin (1986b) confirmed the presence of this structure in all Auchenorrhyncha and Coleorhyncha, but absence in Sternorhyncha and Heteroptera. Based on the variable placement of the sensory pit on the maxillary plate or gena in Fulgoroidea, Bourgoin speculated about its dubious homology with the maxillary palp.

\section{CONCLUSIONS}

The head of Auchenorrhyncha is strongly variable in its shape, but has distinct patterns within separate families, subfamilies, and tribes. These patterns should be used as important characters for resolving phylogenetic relationships among higher lineages of Auchenorrhyncha.

Nymphs of Auchenorrhyncha are more useful for understanding the head structure than adults.

ACKNOWLEDGEMENTS. Special thanks to the people who collected leafhopper nymphs and provided them for this study: A.F. Emeljanov and V.M. Gnezdilov (Zoological Institute, Russia, St. Petersburg); C.H. Dietrich, J.N. Zahniser, and R.A. Rakitov (Illinois Natural History Survey, USA, Champaign);
D.M. Takiya (Universidade Federal do Rio de Janeiro, Brazil); I. Dworakowska, and others. Illustrations of Permuralia rodendorfi used with permission by J. Kukalová-Peck (Carleton University, Ottawa, ON, Canada). C. Dietrich, T. Catanach (Illinois Natural History Survey, USA, Champaign), P. Lauterer (Moravian Museum, Czech Republic, Brno), P. Štys, (Charles University, Czech Republic, Praha), and an anonymous reviewer provided constructive criticism that greatly improved the manuscript. The study has been partially supported by the National Science Foundation grants DEB-0315373, DEB0715499 , and DEB-0529679.

\section{REFERENCES}

Anufriev G.A. \& Emeljanov A.F. 1988: Suborder Cicadinea (Auchenorrhyncha). In Ler P.A. (ed.): Opredelitel' Nasekomykh Dal'nego Vostoka SSSR. 2. [Keys to the Insects of the Far East of the USSR. 2.] Nauka, Leningrad, pp. 12-495 [in Russian, translated into English in 2001].

BourgoIN T. 1986a: Morphologie imaginale du tentorium des Hemiptera Fulgoromorpha. Int. J. Insect Morphol. Embryol. 15: 237-252.

BouRgorn T. 1986b: Valeur morphologique de la lame maxillaire chez les Hemiptera: remarques phylogénétiques. Ann. Soc. Entomol. (N.S.) 22: 413-422.

CoOK E.F. 1944: The morphology and musculature of the labrum and clypeus of insects. Microentomology 9(1): 1-35.

Dietrich C.H. 2004: Phylogeny of the leafhopper subfamily Evacanthinae with a review of Neotropical species and notes on related groups (Hemiptera: Membracoidea: Cicadellidae). Syst. Entomol. 29: 455-487.

Dietrich C.H. \& DMitriev D.A. 2003: Reassessment of the leafhopper tribes Koebeliini and Grypotini Haupt (Hemiptera: Cicadellidae). Ann. Entomol. Soc. Am. 96: 766-775.

Dietrich C.H., Rakitov R.A., Holmes J.L. \& Black V.C. 2001: Phylogeny of the major lineages of Membracoidea (Insecta: Hemiptera: Cicadomorpha) based on 28S rDNA sequences. Mol. Phylog. Evol. 18: 293-305.

DMitRIEv D.A. 2001: Larvae of some species of the subfamily Eupelicinae (Homoptera: Cicadellidae). Zoosyst. Rossica 9[2000]: 353-357.

DMITRIEV D.A. 2002a: General morphology of leafhopper nymphs of the subfamily Deltocephalinae (Hemiptera: Cicadellidae). Acta. Entomol. Slovenica 10(1): 65-82.

DMitRIEv D.A. 2002b: Larvae of the leafhopper subfamily Deltocephalinae (Homoptera, Cicadellidae) from European part of Russia and adjacent territories. I. A key to tribes and review of the tribes Drabescini, Scaphytopiini, Hecalini, Limotettigini, and Opsiini. Entomol. Obozr. 81: 627-661 [in Russian; translated into English in Entomol. Rev. 82: 975-100].

DMitriev D.A. 2003: Larvae of leafhoppers of the subfamily Deltocephalinae (Homoptera, Cicadellidae) from European Russian and adjacent territories. II. Tribes Grypotini, Selenocephalini, Goniagnathini, Fieberiellini, Tetartostylini, Macrostelini, and Doraturini. Entomol. Obozr. 82: 650-686 [in Russian; translated into English in Entomol. Rev. 83: 665-695].

DMitriev D.A. 2004a: Nymphs of some species of the tribes Drabescini and Paraboloponini with a proposed synonymy of Paraboloponini with Drabescini (Hemiptera: Cicadellidae: Deltocephalinae). Orient. Insects 38: 235-244.

DMitRiEv D.A. 2004b: Larvae of leafhoppers of the subfamily Deltocephalinae (Homoptera, Cicadellidae) of European Russia and adjacent territories. III. The tribes Deltocephalini, 
Stirellini, and Paralimnini. Entomol. Obozr. 83: 87-114 [in Russian; translated into English in Entomol. Rev. 84: 31-53].

DMitRIEV D.A. 2006: Larvae of leafhoppers of the subfamily Deltocephalinae (Homoptera, Cicadellidae) of European Russia and adjacent territories. IV. The tribe Athysanini. Entomol. Obozr. 85: 75-121 [in Russian; translated into English in Entomol. Rev. 86: 11-48].

DuPorte E.M. 1946: Observations on the morphology of the face in insects. J. Morphol. 79: 371-417.

DuPorte E.M. 1962: The anterior tentorial arms in insects and their significance in interpreting the morphology of the cranium of the Cicadas. Can. J. Zool. 40: 137-144.

EMELJANOv A.F. 1995: To the question of classification and phylogeny of the family Delphacidae (Homoptera, Cicadellidae), with reference to larval characters. Entomol. Obozr. 74: 780-794 [in Russian; translated into English in Entomol. Rev. 75: $134-150]$.

Evans J.W. 1938: The morphology of the head of Homoptera. Pap. Proc. R. Soc. Tasman. 1937: 1-20.

Evans J.W. 1953: Les Cicadellidae de Madagascar (Homoptères). Mém. Inst. Sci. Madagascar. (E) 4: 87-137.

Evans J.W. 1957: Some aspects of the morphology and interrelationships of extinct and recent Homoptera. Trans. R. Entomol. Soc. Lond. 109: 275-294.

Evans J.W. 1968: Some relict New Guinea leafhoppers and their significance in relation to the comparative morphology of the head and prothorax of the Homoptera - Auchenorrhyncha (Homoptera: Cicadellidae: Ulopinae). Pac. Insects 10: $215-229$.

Evans J.W. 1973: The maxillary plate of Homoptera - Auchenorrhyncha. J. Entomol. (A) 48(1): 43-47.

Evans J.W. 1975: The external features of the heads of leafhoppers (Homoptera, Cicadelloidea). Rec. Austral. Mus. 29: 407-440.

FERRIS G.F. 1942: Some observations on the head of insects. Microentomology 7(2): 25-62.

FERRIS G.F. 1943: The basic materials of the insect cranium. Microentomology 8(1): 8-24.

FERRIS G.F. 1944: On certain evolutionary tendencies in the heads of insects. Microentomology 9(2): 78-84.

HAMILTON K.G.A. 1981: Morphology and evolution of the rhynchotan head (Insecta: Hemiptera, Homoptera). Can. Entomol. 113: 953-974.

Hamilton K.G.A. 1999: The ground-dwelling leafhoppers Myerslopiidae, new family, and Sagmatiini, new tribe (Homoptera: Membracoidea). Invertebr. Taxon. 13: 207-235.

KuKALOVÁ-PeCK J. 1985: Ephemeroid wing venation based upon new gigantic carboniferous mayflies and basic morphology, phylogeny, and metamorphosis of pterygote insects. Can. J. Zool. 63: 933-955.

KukalovÁ-Peck J. 1987: New carboniferous Diplura, Monura, and Thysanura, the hexapod ground plan, and the role of tho- racic side lobes in the origin of wings (Insecta). Can. J. Zool. 65: $2327-2345$.

KukalovÁ-Peck J. 1991: Fossil history and the evolution of hexapod structures. In: The Insects of Australia. A Textbook for Students and Research Workers. Vol. 1. 2nd ed. Cornell Univ. Press, Ithaca, New York, pp. 141-179.

KukalovÁ-Peck J. 1992: The "Uniramia" do not exist: the ground plan of the Pterygota as revealed by Permian Diaphanopterodea from Russia (Insecta: Paleodictyopteroidea). Can. J. Zool. 70: 236-255.

KuKalovÁ-Peck J. 2008: Phylogeny of higher taxa in Insecta: Finding synapomorphies in the extant fauna and separating them from homoplasies. Evol. Biol. 35: 4-51.

LEW G.L. 1960: The external morphology of the last-instar nymph of Magicicada septendecim (L.) (Hemiptera: Homoptera). Entomol. Am. 39: 101-182.

Matsuda R. 1965: Morphology and evolution of the insect head. Mem. Am. Entomol. Inst. 4: I-VII, 1-334.

MeJdalani G. 1998: Morfologia externa dos Cicadellinae (Homoptera, Cicadellidae): comparação entre Versigonalia ruficauda (Walker) (Cicadellini) e Tretogonia cribrata Melichar (Proconiini), com notas sobre outras espécies e análise da terminologia. Rev. Brasil. Zool. 15: 451-544.

Oman P.W. 1949: The Nearctic leafhoppers (Homoptera: Cicadellidae). A generic classification and check list. Mem. Entomol. Soc. Wash. 3: 1-253.

Oman P.W., Knight W.J. \& Nielson M.W. 1990: Leafhoppers (Cicadellidae): A bibliography and generic check-list and index to the world literature 1956-1985. C.A.B. International, Wallingford, Oxon, $368 \mathrm{pp}$.

Parsons M.C. 1964: The origin and development of the hemipteran cranium. Can. J. Zool. 42: 409-432.

SNODGRASS R.E. 1935: Principles of Insect Morphology. McGraw-Hill, New York \& London, 677 pp.

SNodgrass R.E. 1947: The insect cranium and the "epicranial suture”. Smithson. Misc. Coll. 107(7): 1-52.

SPOONER C.S. 1938: The phylogeny of the Hemiptera based on a study of the head capsule. Illinois Biol. Monogr. 16(3): $1-102$.

Wagner W. 1951: Beitrag zur Phylogenie und Systematik der Cicadellidae (Jassidae) Nord- und Mitteleuropas. Comm. Biol. 12(2): 1-43.

Yoshizawa K. \& Saigusa T. 2003: Reinterpretations of clypeus and maxilla in Psocoptera, and their significance in phylogeny of Paraneoptera (Insecta: Neoptera). Acta Zool. (Stockholm) 84: 33-40.

Zahniser J.N. \& Dietrich C.H. 2010: Phylogeny of the leafhopper subfamily Deltocephalinae (Hemiptera: Cicadellidae) based on molecular and morphological data with a revised family-group classification. Syst. Entomol. 35: 489-511.

Received September 23, 2009; revised and accepted May 17, 2010 